\title{
Access to Finance: Impacts of Publicly Supported Venture Capital and Loan
}

Guarantees

Compendium of Evidence on the Effectiveness of Innovation Policy Intervention

Dr Ronnie Ramlogan

Dr John Rigby

Manchester Institute of Innovation Research Manchester Business School, University of Manchester http://research.mbs.ac.uk/innovation/ 
This report is part of the Compendium of Evidence on the Effectiveness of Innovation Policy Intervention Project led by the Manchester Institute of Innovation Research (MIoIR), University of Manchester. The project is funded by the National Endowment for Science, Technology and the Arts (NESTA) - an independent body with the mission to make the UK more innovative.

The compendium is organised around 20 innovation policy topics categorised primarily according to their policy objectives. Currently, some of these reports are available.

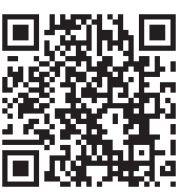

All reports are available at http://www.innovation-policy.org.uk. Also at this location is an online strategic intelligence tool with an extensive list of references that present evidence for the effectiveness of each particular innovation policy objective. Summaries and download links are provided for key references. These can also be reached by clicking in the references in this document. 


\section{Table of Contents}

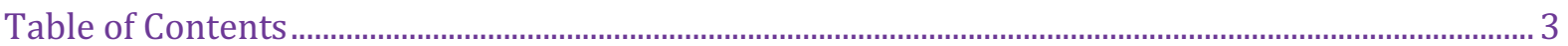

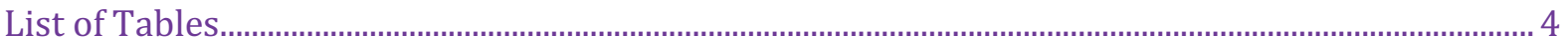

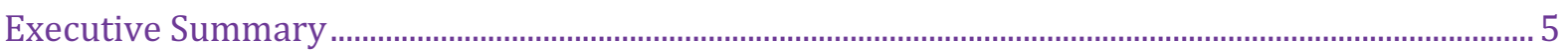

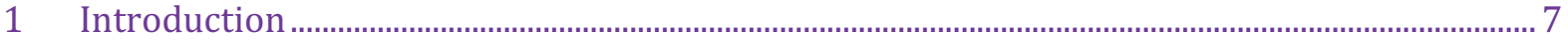

1.1. The Midas Touch - Public Policy Rationales................................................................................... 7

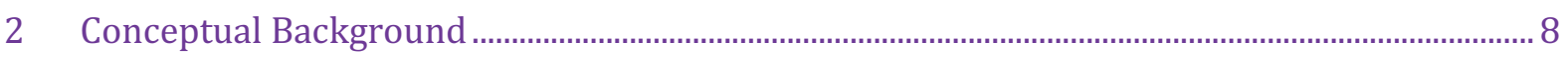

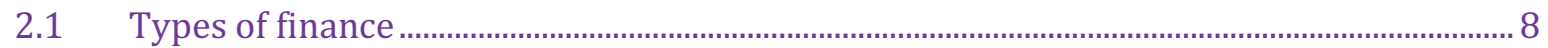

$2.2 \quad$ Rationales for Public Policy Intervention ................................................................................ 10

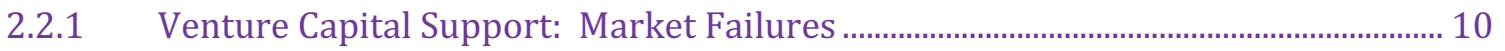

2.2.2 Market Failures and Access to Equity ........................................................................... 11

2.2.3 Market Failures and Loan Guarantees .................................................................................. 13

2.2.4 An Institutionalist Perspective................................................................................... 14

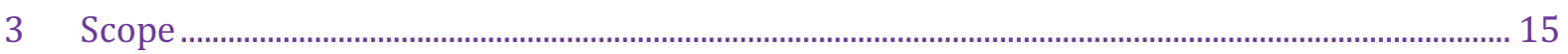

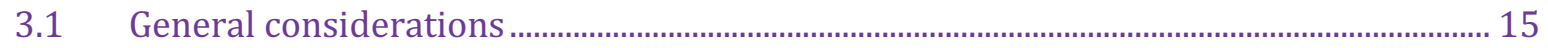

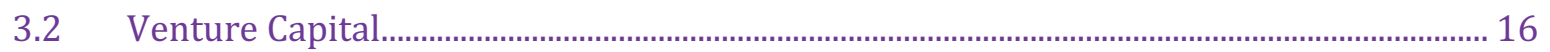

3.3 Scope for Credit Guarantee Schemes ................................................................................ 17

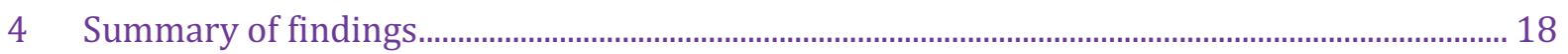

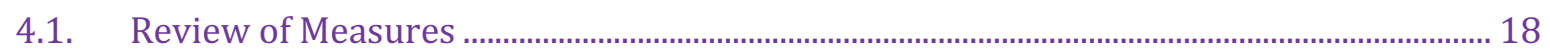

4.2. Publicly Supported Venture Capital: How effective are these initiatives? ........................ 18

4.2.1. Introduction ................................................................................................................. 18

4.2.2. Easing Access to Finance ……………….............................................................. 19

4.2.3. Impacts within the Firm: Productivity, Employment, Turnover, Exports ................ 20

4.2.4. The Additionality Dimension..................................................................................... 21

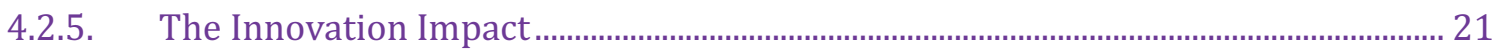

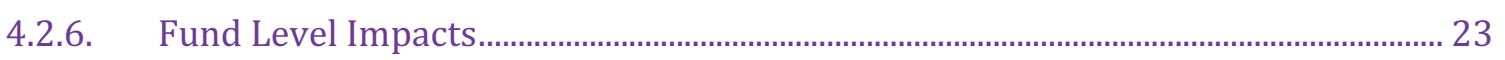

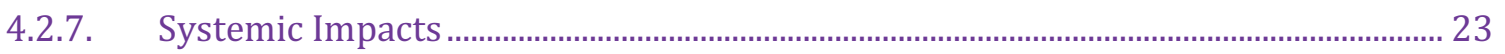

4.3. Loan Guarantees: How effective are CGS? ........................................................................... 27

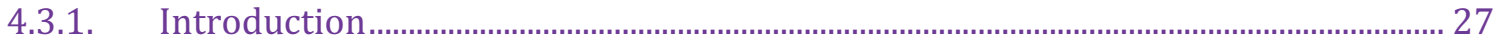

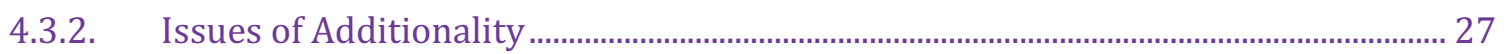

4.3.3. An overview of the evaluation evidence ......................................................................... 29

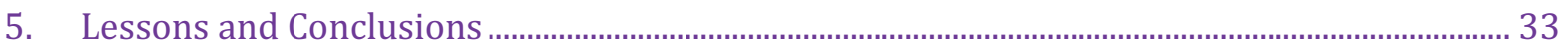

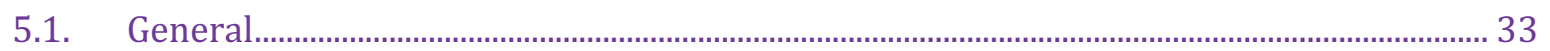

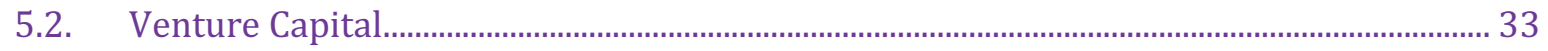

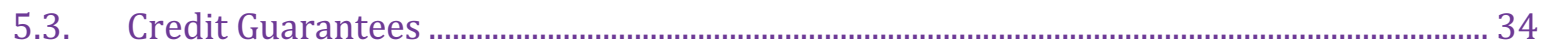

5.4. Common Issues and Final Observations................................................................................. 35

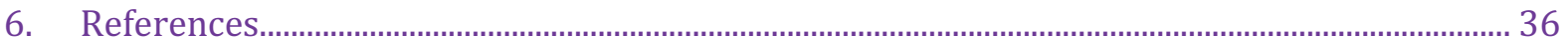

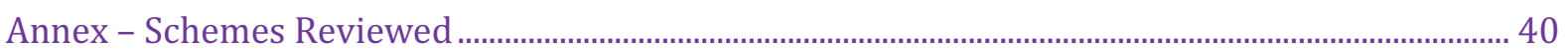




\section{List of Tables}

Table 1 Reviews of Venture Capital Support Measures............................................................................... 26

Table 2 Review of Loan Guarantee Support Measures. 


\section{Executive Summary}

This report examines government measures that have been taken to provide firms with access to finance. This covers measures that provide real financial help to firms, i.e. they are a form of financial assistance or subsidy to firms. The two types of policy measures considered are publicly supported venture capital and government backed loan guarantees.

The report first introduces in section two the types of policy measures that we have reviewed while section three explains the scope of sources and material analysed.

In general we find that evaluations conducted on these measures employ a range of approaches to assess performance, some of which are simply descriptive, some of which involve comparisons but very few of which attain the level that can control for the selection bias effects that would help to measure the net impacts of policy.

Very few initiatives are specifically directed at causing innovation as such. Support in the form of venture capital assistance or loan guarantees is intended in the first instance to provide the resources that firms need to grow. Programme designers expect access to finance to lead to increases in turnover and employment which will accompany innovation.

A number of measures seek to promote innovation but in some cases the schemes have been designed and implemented in such a way as to protect firms. This may weaken selection pressures. Few venture capital scheme reviews carry out comparison using matched pairs and account explicitly for selection bias.

Impacts of programmes assessed are usually employment and turnover, with some consideration given to export performance (internationalization) in some schemes. Patenting is also considered in a small number of evaluations.

Some venture capital programmes are very concerned with the creation of systemic effects. Systemic effects are where programmes seek to improve the private capability in the area of investment, i.e. the supply side, with a view to increasing the overall level of funds available for investment, thereby removing or ameliorating the market failure. This is because the investment infrastructure is less easy to preserve and is especially likely to decline in effectiveness during periods of economic difficulty. Some evaluations consider systemic effects on the demand side to be required to solve the problem of the low number of new firms created and the low growth rate of firms.

While some of the evaluations we have examined have been attentive to the impact of finance upon innovation, an issue that we interpreted as at the core of this report, no work has taken the broad and long term economic impacts of the innovations thus funded into account. We therefore do not have a good sense of how important this form of funding is in terms of major impacts upon the economy. More fundamental lessons could be learned therefore about the economic impacts by widening the scope from innovation to commercialisation of innovation. We note that evaluations of schemes that take these effects into account have not been possible to find. 
With respect to publicly supported credit guarantee schemes, we note the following points:

While metrics such as default rate and economic or financial additionality provide evidence about the performance of schemes, better comparisons are not possible as there is no consistent standard for measurement of the schemes.

Credit guarantee schemes have not been particularly directed to supporting innovation activities and of the studies considered innovation has been the focus of attention of the KOTEC scheme in Korea.

To the extent that there was credit rationing, credit guarantee schemes have contributed to relaxing this constraint for SMEs in many countries and in different economic climates.

Credit guarantee schemes help businesses to grow. Several evaluations show a direct causal effect on output (sales) and employment. However the evidence when considered also indicates that some schemes did not impact of firm productivity, R\&D or investment intensity. In such circumstances schemes may actually be supporting struggling firms and ultimately stifling innovative forces.

Finally, one of the more common concerns in our analysis of venture capital support and credit guarantees is the issue of moral hazard. Credit guarantee schemes reduce the incentive and commitment of borrowers to repay loans. Evidence shows that even in the most 'careful' schemes borrowers adopt risky strategies. Moral hazard exists on the part of banks also as studies have shown that in some cases there was less incentive to supervise loans properly. Moral hazard also affects venture capital support measures that have government support. Evaluations of government supported venture capital funds show the importance of the design of the compensation arrangements in the sharing of risk between investing bodies and those organisations in which investments are made.

The a priori assumption, which we ourselves have not made but which others may have done, that these two forms of government backed financial assistance would lead equally to innovation within the firm and the economy is difficult to establish with the evidence provided by the studies we have evaluated. Moreover, these two forms of financial assistance do have different purposes in that they support firms at different stages of their evolution, and we would expect VC support schemes would target firms at the pre-market and more risky phase of development than credit guarantees. 


\section{Introduction}

This report examines government measures that have been taken to provide firms with access to finance. This covers measures that provide real financial help to firms, i.e. they are a form of financial assistance or subsidy to firms. While the mode through which this assistance is given in both equity and loan guarantees is indirect as the assistance comes through organisations partly or wholly private, "access to finance" measures as they are covered by this report refer therefore not to measures that advertise financial support in the sense of giving information about where such finance can be found or in the sense of providing access to potential investors.

In particular the report is concerned with venture capital (equity) and debt finance and measures developed by governments to support their provision with the additional prerequisite that such initiatives should facilitate innovation. Our report seeks to identify factors key factors of the measures - that lead to innovation in order to identify what government policies work in stimulating innovation. These types of measure are not considered as substitutes in that they are intended for and are normally used by firms at different stages of their development. Debt finance is a widely used and relatively inexpensive way through which a firm can raise finance. It tends to be utilised by low risk businesses. Loans and overdrafts are the most common forms of debt finance. Equity finance (especially venture capital) is usually associated with businesses which have great potential for growth but which are high risk ${ }^{1}$. Such businesses may be at an early stage and lack cash flow and security in order to obtain debt finance. Venture capitalists provide finance in return for an equity stake in the business (BIS 2012). Firms that have greater levels of uncertainty as to their future performance are generally firms that are early stage and small - even if there instances of where significant financial support has been provided to larger firms, for example the case of launch aid to Airbus Industrie (WTO 2010). Especially early stage and small firms will usually seek financing in the form of equity investment which carries greater risks for the investor but also greater potential rewards.

\subsection{The Midas Touch - Public Policy Rationales}

For over decade there have been a range of studies that argued that finance (forms of venture capital and or loans) were important to the economy as a whole because these investments more than any other investments made by large corporates were more effective in generating innovation (Kortum and Lerner 2000; Jeng and Wells 2000). Their analysis suggested that investments made in small firms were far more likely to generate patents than investments made by large corporates. The argument was a seductive one from the point of view of policy makers and venture capitalists seeking to bend policymakers' ears with proposals of hybrid funds.

Our analysis has examined the issue of policy schemes that provide access to finance and do so with the intention of leading to innovation. The report first introduces the types of policy measures that we have reviewed (Section 2) and in Section 3 explains the scope of sources and material analysed. We then report in Section 4 the findings of our review of the studies that

1 The distinction between forms of equity investment is often blurred, as a number of commentators have observed (Pierrakis 2012). 
have considered the operation of the various measures. In section five we present our lessons and conclusions.

\section{Conceptual Background}

\subsection{Types of finance}

This review is concerned with the two major forms of finance -venture capital which is one form of equity financing, and debt finance - that have been used in the support of firms that fail to obtain private investment but which, objectively viewed, may have realistic growth prospects. Policy makers have generally argued that the failure of firms to find finance for growth is a consequence of market failure both on the demand and the supply side. On the demand side it has been argued that firms lack the capacity to locate suitable financial support; and on the supply side it has been argued that the structuring and incentives of the financial sector and indeed recent history of economic decline have led to under provision of the finance to those who might be able to use it effectively. Two main forms of argument have been put forward to explain why such problems exist and why a public policy solution should be found. While the first argument, market failure, provides the essential justifications, we believe that attention should be paid to the institutions of finance themselves and this is why we have included a sub-section on these issues in that understanding of the details of financing decisions (in particular the granting of loans) provides a better basis for the making of public policy.

The Rowlands Report (BIS 2009), which considered how intervention might increase the supply of long term growth capital to SMEs, neatly summarizes the range of financial instruments (products?) that are available for supporting SMEs in the UK. They range from grants and informal lending covering relatively small financing requirements and risk on the one hand to investments with risks of a more substantive nature that can be obtained from private equity or public markets on the other. Figure 1 shows the range of products with the associated risk/return profile.

Figure 1 Types of SME Financing

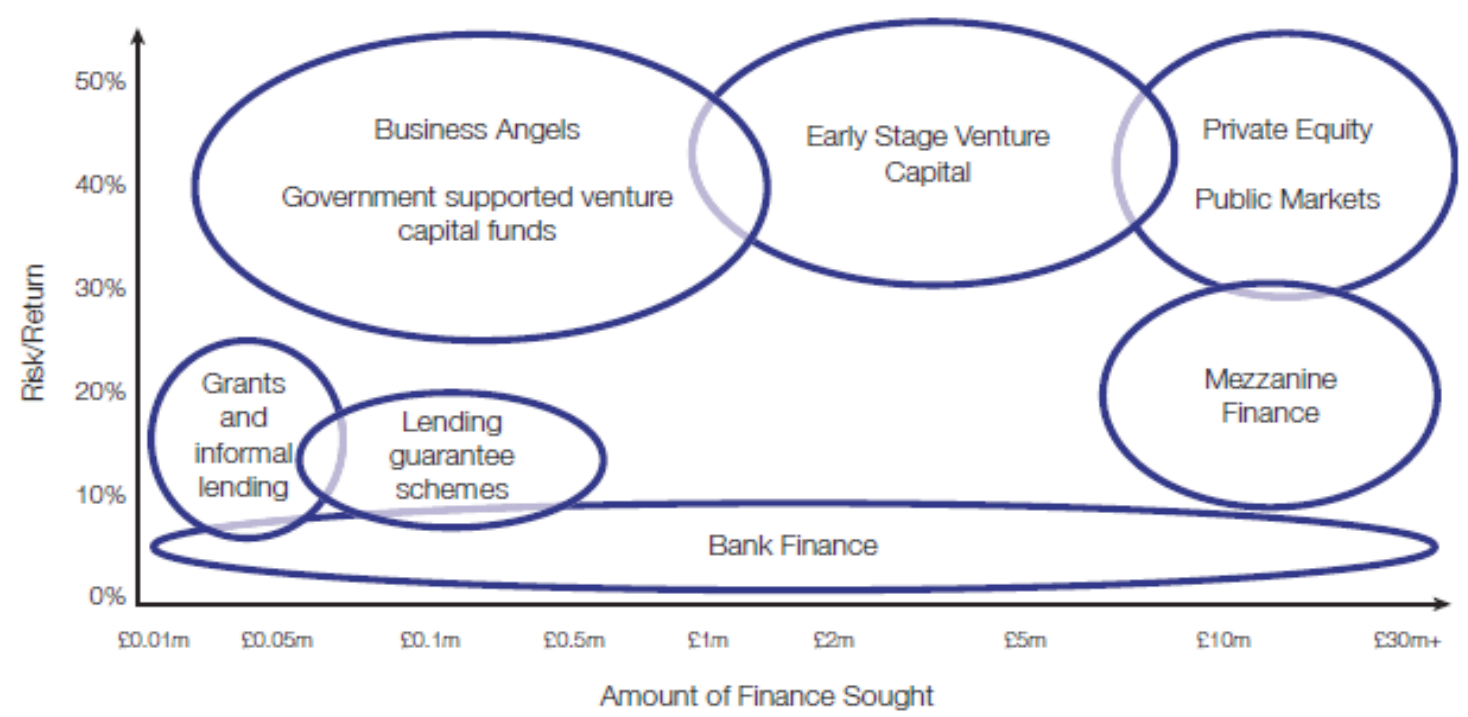

Source: BIS (2009). 
Financial support to small firms can be provided in a number of ways, not only in terms of subsidizing equity investments or loans but through other means.

For example, as the NAO (2009, p. 14) report indicates, government support for the financing of firms can include the following types of activity:

- RDA equity and loans funds

- Other government equity investment

- Improving investor readiness

- Promoting investor activity

- Tax schemes (enterprise investment scheme venture capital trusts)

These various forms of support by government comprise indirect financial support; the provision of information and capabilities, and the dissemination of information about specific opportunities for firms and investing companies; the use of the tax system to incentivize usually wealthy individuals to invest in those kinds of firms that might not have access to the levels of investment that they need. OECD notes these last forms for support are termed public subsidies

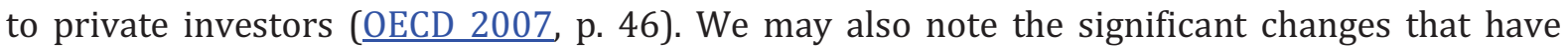
occurred in the way in which the industry functions over its relatively short life (Gompers and Lerner 2001).

As indicated above we have chosen to cover publicly supported venture capital and loan guarantees schemes. The relationship between venture capital and innovation has come under much scrutiny in recent years. Most policy makers often assume that venture capital has a positive impact on innovation. However, the empirical literature suggests a very mixed picture. Kortum and Lerner (2000) present a venture capital first account; that is, the presence of venture capital leads to firms innovating. But various other studies (Engel and Keilbach 2007; Hirukawa and Ueda 2008; Caselli et al. 2009; Lahr and Mina 2012; Popov and Roosenboom 2012), all support the hypothesis that venture capital does not foster new innovations but instead invests in already innovative firms. Nevertheless while the direction of causation is yet to be determined, there is still a strong association between venture capital and innovation.

By comparison, in the case of loan guarantees, the relationship with innovation is much more opaque. The overall aim of loan guarantee programmes is to improve levels of bank lending to SMEs. While most programmes do not explicitly have innovation related objectives (e.g. increasing R\&D spending), the assumption of indirect effects on innovation and R\&D is not implausible. There are however a number of programmes that specifically target innovation and /or R\&D. An expert report of 2003 (Report to the European Commission by an Independent Expert Group 2003) for example points to the schemes such as the UK's Small Business Loan Guarantee schemes where, according to the 1999 evaluation, 53\% of firms stated they were using the loan to finance new products or services or the Finanzierungsguarantee Gesellschaft Technology Financing Programme in Austria that offers a combination of equity and loan guarantees for technology-oriented SMEs. ${ }^{2}$

2 A European Union loan guarantee facility for innovative small and medium-sized enterprises (SMEs) has recently been launched in Austria. The Risk Sharing Instrument aims to encourage banks to provide loans and leases of between $€ 25,000$ and $€ 7.5$ million to SMEs and small mid-caps 
It is worth noting that these measures including venture capital and loan guarantee may be commonly used together as part of a platform of measures in developed economies and it is not unlikely that such measures do interact i.e. they are mutually supporting, and should be considered together. Another area that is important but which is beyond the remit of this report is that of the taxation of private equity income by general partners, for a brief account of this see the recent ICAEW publication (Institute of Chartered Accountants of England and Wales 2010).

\section{Terminological Issues - Hybrid Funds, Guarantees}

We note that the term "hybrid fund" has been used in the literature to describe equity investment schemes that are government backed. We cover hybrid funds in this review and this term covers the majority of forms of support for equity investment. We also note that the term "guarantee", while traditionally applied to loans, has, over the last five years (since around 2007) become applicable to equity finance. Equity guarantee finance, where government, or a government agency, guarantees investments made by private organisations to other private organisations (usually SMEs) in the equity of these investee companies is a new departure. Such an investment ultimately takes the form of equity in the firm rather than a loan. Organisations such as Finnvera in Finland provide guarantees for loans or venture capital investment.

Figure 2 Main Types of Support: Venture Capital and Credit Guarantees

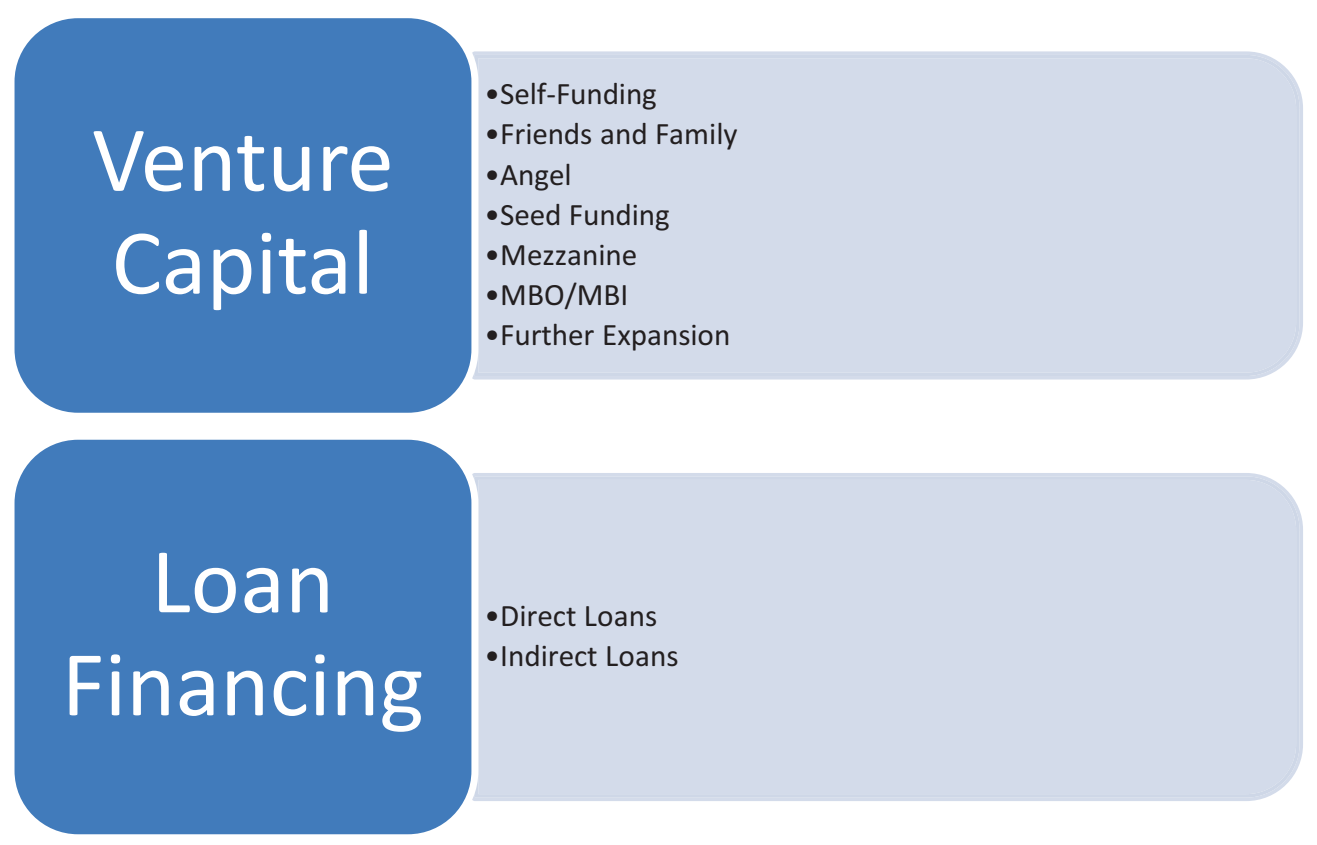

\subsection{Rationales for Public Policy Intervention}

\subsubsection{Venture Capital Support: Market Failures}

Why should governments intervene in venture capital markets? The literature recognises two types of market failure arguments that are appropriate in the context of venture capital. The first relates to information asymmetry. Innovators or young high tech firms know much more

undertaking research, development or innovation, and seeking finance for investments and/or working capital (http://europa.eu/rapid/press-release_IP-12-1053_en.htm) 
about their own capacities and the risks of the projects being developed than potential investors. Such information asymmetry leads to adverse selection (Akerlof 1970) and to moral hazard / agency problems (Arrow 1974; Stiglitz and Weiss 1981). Investment funds are therefore in short supply (financing gap) for young firms in high technology sectors seeking resources to facilitate their growth. The second market failure relates to externalities associated with R\&D and innovation (Jaffe 1996). Innovation and R\&D related projects arguably generate significant social benefits (positive spillovers). To the extent that venture capital investors are deterred from investing in innovation and R\&D because they are unable to fully appropriate the returns from their investments there will be under-provision of innovation and hence unrealised social benefits. Both information asymmetry and externality based market failures therefore provide a socially sub optimal outcome resulting in low levels of entrepreneurship. Hence this provides a justification for a public response through subsidising venture capital. But the rationales for government action are not always clear and the results not always positive (Murray 2007).

\subsubsection{Market Failures and Access to Equity}

As we have noted above, financial support to small firms that are at the earliest stage of their development and in which investment represents a high risk to investors will often receive investment in the form of equity. The term given to such investment in the equity of firms i.e. investment in the firms that involves granting some ownership of the firm from private sources is "private equity" (EKOSGEN 2011). Private equity takes a number of forms depending upon the stage of development of the investee. Classification can be according to the stage at which the investment is made or to reflect the type of actor involved. For example, EKOSGEN uses the following three sub-types of "private equity": angel investing, venture capital, and private equity; while in the BCVA and NESTA framework (British Venture Capital Association and NESTA 2009, p. 26) a fourth category is defined as "friends and family" which takes the place of the very first stage investors. Bessant and Tidd (2007) note five forms for new venture funding: self funding, family and friends, business angels, bank loans and government schemes, but he also notes four main stages: a) initial funding for launch; b) second-round financing for initial development and growth; c) third-round financing for consolidation and growth; d) and maturity and exit. We note that the use of the term private equity often refers to the entire set of investment types and also to the later stage investments where greater investment expertise is brought to bear on the investment and larger amounts of funds are disbursed. The EKOGEN categorization uses the following four stages of investment in its analysis: Early stage; MBO/MBI; Expansion; Other Stage (EKOSGEN 2011, p. 21) while OECD uses four described as follows: Seed; start-up; other early stage; expansion or late stage (OECD 2012).

\subsubsection{Equity - Demand Side}

The market failures that are held to provide the justification for government involvement have, as we note above, been considered to exist on both demand and supply side. On the demand side, it has been claimed:

a) that companies with prospects do, in spite of their potential, fail to "present themselves a investable opportunities due of poor business plans or inadequate business skills,... [thereby constraining] their ability to invest. 
We also note that:

b) small firms that need investment, and which cannot secure loans because of the risks they present to investors, are reluctant to accept equity investment because such investment dilutes the ownership and control of the business. Equity investment right along the investment spectrum from the very early stage through to large private equity investments in established businesses runs such risks of creating conflict with investors ${ }^{3}$, many of whom will seek payback within a short period of time. Why such conflicts cannot be ruled out through suitable drafting of legal agreements (which would remove the risk and the cause of market failure) is clear: uncertainty in the development of such firms is great and the course of their development cannot be determined.

\subsubsection{Equity - Supply Side}

On the supply side, five reasons are generally given why investors are reluctant to provide investment to firms that might be likely to grow to which a later rationale given by NESTA in 2009 might be added, the sixth in our list:

a) Firms that need investment at the early stage are high risk, some will grow, but many will fail and prediction is not accurate such that the costs, which are high and often indivisible, cannot be offset by the returns even for small venture capital investors;

b) It has been argued that the historical legacy of very poor and negative performance has altered investor perceptions to the point where they do not reflect reality, leading to an insufficiency of capital for investment by private individuals - (such an argument relies upon the claim that actors are in fact irrational);

c) It has also been contended that the investment professionals (as opposed to institutional investors) have begun to focus upon later stage investments where returns are greater, thereby leaving the early stage part of the market for investment funds under resourced ${ }^{4}$. The predominance of interest at the "higher" end of the investment spectrum is in part owing to the tradition of the so-called "carried interest" whereby investment managers take a profit share proportion to the size of the deal they process, giving them an incentive to work only on the larger deals. The issue is similar to the indivisibility problem noted in a);

d) Institutional investors considering exclusively their own returns on their investment do not believe the risks of investing in small firms can ever be high enough to match the benefits of investing in larger firms particularly as realization of the value of illiquid assets of small firms are likely to be low.

e) Firms understand better the risks that they face than potential investors, such information asymmetries leading to underinvestment.

f) An additional problem that may arise is that markets in which information is exchanged relating to small firms are "thin" (British Venture Capital Association and NESTA 2009). These

${ }^{3}$ As occurred in the case of Montagu Private Equity's investment in GHD.

4 A Report by the Kauffman Foundation provides some general evidence of dissatisfaction over the incentive structures that have developed in the VC funding industry over the last two decades Mulcahy et al. (2012). 
information asymmetries arise from the infrequency of trading in assets and have the consequence that under investment follows because markets do not set prices reliably.

While action to address the market failures associated with the positive externalities of innovation is broadly justified, the scope for "correction" or the addressing of such market failures of information is as a number of commentators have noted, not clear, and could be very limited. Thus, Brander et al. (2008) feel justified in cautioning against government action here: "Despite these informational market failures, it is highly questionable as to whether government intervention can reasonably resolve the informational problems directly. Governments cannot readily reduce informational asymmetries. One approach to reducing informational asymmetries is to impose strengthened disclosure requirements (as with the much-discussed Sarbanes-Oxley legislation in the U.S.). However, such requirements impose costs and are of questionable merit even for large and established publicly traded corporations. In the entrepreneurial sector, imposing additional disclosure requirements would probably create an excessive and unworkable burden for many entrepreneurial ventures" (Brander et al. 2008, p. $5)$.

We turn now to the issue of debt finance.

\subsubsection{Market Failures and Loan Guarantees}

As Lerner (2002) notes, young and high-tech firms in particular, face great difficulties in accessing the loan markets. Indeed the belief that capital markets do not provide adequate funds for new businesses is one of the fundamental rationales behind government loan assistance programs for SMEs (Evans and Jovanovic 1989). Such interventions are based on the widely held perception that the small business sector is an essential element for economic growth; it is an incubator where innovation can arise and new ideas transformed into economically profitable and sustainable business enterprise (Rigby et al. 2012).

There is now a considerable body of theoretical (and empirical work) that attempts to explain credit rationing or justify government intervention in credit markets. This debate is predicated on the assumption that guarantees can lead to an improvement in economic welfare. However for this to be so, there must be a credit market failure and further, any intervention on the part of public authorities must introduce fewer distortions that it resolves (Honohan 2010). A common starting point in relation to credit market failure focuses on the role of information asymmetries between banks and firms. The seminal paper by Stiglitz and Weiss (1981) shows how imperfect information can lead to two problems that result in a failure of the credit market allocation mechanism. The first is the problem of adverse selection. Since the 'quality' of the borrower is unknown to the bank, it is unable to offer a contract that reflects the respective specific level of risk. Increasing price (interest rate) affects the nature of the transaction since those prepared to pay high interest charges may on average be worse risks for the bank. Adverse selection thus impedes the ability of markets to allocated credit using price by attracting high-risk borrowers. The second problem, moral hazard, reduces the ability of prices to clear lending markets because it influences the ex post actions of borrowers as they may be incentivized by any increases in the cost of borrowing to switch to projects with greater risk.

Credit rationing is also likely to occur when banks insist on taking collateral (Cowling and Mitchell 2003; Honohan 2010). Collateral can act as a sorting device (Bester 1985; Besanko and Thakor 1987); it substitutes for information and can limit the potential loss for the lending bank 
(Boocock and Shariff 2005). It also a strong signal that the entrepreneur believes the project is likely to succeed since only good risk borrowers may be prepared to put up collateral against a loan. However as Vogel and Adams (1997) note, the fact that small firms may be excluded from loans if they do not have sufficient collateral is not an imperfection in the credit market but part of its normal operations. Given their stage of development and even if SMEs have high quality projects, they may be not be able to provide collateral required by bankers.

Honohan (2010) expresses some reservations about the extent to which the adverse information problem or the lack of collateral provides a sufficient justification for intervention. While loan guarantee schemes help SMEs avoid the adverse information problem that leads to credit rationing in Stiglitz-Weiss type of model because of the lower (subsidized) interest rate implied with the guarantee, there is no reason why any guarantor would have an information advantage relative to the bank. Further, although low wealth individuals and groups are unlikely to have sufficient collateral, it is unclear whether improving credit allocation is best instrument to correct for unequal initial endowments. Instead, Honohan (2010) argues that intervention could be justified slightly differently: as a means to kick start SME lending or for offsetting a credit crunch. The former is, in effect a 'learning by doing' argument. SME lending is not well developed because banks lack experience dealing with SMEs, hence face a lengthy lossmaking start-up period. Eventually the lenders may acquire sufficient skill and information to continue to lend to the sector without the need for the credit guarantee. In the case of the latter, intervention can be justified when transitory increases in uncertainty lead to information deficiencies and market failure. In such contexts subsidizing the business cycle on a temporary basis might prove to be welfare enhancing.

SME financing issues however arise not solely on the supply side and Roper (2011) points to recent research that highlights demand-side aspects both in terms of the reluctance of SMEs to take advantage of external finance and the 'investment readiness' of many SMEs. He suggests that pecking order models show that firms, due to adverse selection, prefer internal to external finance and even in cases when external funds are necessary, the preference is for debt rather than equity due to the lower information and dilution costs. However the issue of external finance raises further questions about the preparedness of some SMEs, the quality of their business planning as well as financial management and governance systems. The implication is that measures to promote SME finance from the supply-side cannot be considered in isolation.

\subsubsection{An Institutionalist Perspective}

As Berger and Udell (2004) have noted in relation to loans, the character of and features of the institutional and legal systems under which lending organisations operate have important effects on how small firms (indeed any firm) access credit. Their analysis suggests that the lending infrastructure has powerful influence upon the access to finance of small firms. The importance of apparently irrelevant details of insurance company regulation to name but one aspect of the institutional systems has also been noted by OECD (2004). The problems of business lending that give rise to a need for policy action stem, in part, according to the authors, from the technology of lending. It is also the case that international standards (mainly the Basel Accords) etc provide an important framework that has consequences for the funding of small firms. This framework includes the following (Berger and Udell 2004, p.3): 
- Credible accounting standards

- Strong effective and enforceable property rights - stemming from effective commercial laws and codes, effective bankruptcy law,

- The state of security interests which affect the status of and quality of collateral in the context of loan financing, this includes the status of the common law right "lien" upon which mortgages are based

- Restrictions on foreign ownership of financial institutions has, in the case of developing nations, appeared to restrict credit to SMEs

- State ownership of lending institutions

- The role of lending technologies, the types being: financial statement lending; small business credit scoring; asset based lending; factoring; trade credit; relationship lending.

This study is not a however a review of the macro-economic effects of policy on lending as it is a major enquiry of its own. However, we do wish to draw attention to the role played by banking regulatory systems upon lending to small firms as the regulatory requirements of the banking system have important consequences for access to finance (Ayadi 2005).

\section{Public Ownership and Intervention}

As we are concerned with public lending, we need to look more closely into the relation between public ownership of lending institutions and policy intervention. While public intervention in private markets for capital and loans can lead to or improve economic efficiency by addressing market failures, it remains the case that public involvement may lead to inefficiencies. In their analysis of the structures and institutions of lending Berger and Udell (2004) note the generally inferior role of publicly owned ("state owned", p. 12) financial institutions may fail to exercise sufficient discipline over the financial investments they make (mainly through lending) to small firms. Such inefficiencies that occur when public organisations are involved in the provision of finance to firms lead to a variety of problems: State-owned institutions may also provide relatively weak monitoring of borrowers and or refrain from aggressive collection procedures as a part of their mandates to subsidize chosen borrowers or because of the lack of market discipline. In nations with substantial state-owned banking sectors there may also be significant spillover effect that discourage privately-owned institutions from SME lending due to "crowding "out effect of subsidized loans from state owned institution or poor credit cultures that are perpetuated by the state-owned presence" (Berger and Udell 2004, p. 12).

\section{Scope}

\subsection{General considerations}

This study, like the others in the series, seeks to examine reports and evaluations that comment on and give specific insight into the operation of measures with a view of defining what works in an area of policy. The scope of our search has therefore been to find reports of measures that give such details. To this extent we are limited by the availability of such studies and reports. Our work is based on a review of the academic literature and the grey literature of government sponsored and government and consultant conducted evaluations of such schemes. Our search was divided into two, to focus on equity funding on the one hand and loan guarantees on the other. 
Reports of appraisals and evaluations were then examined individually to identify those features of the policies that were effective and those which were not. These findings concerning the features that may play some important role in the effectiveness of the measures overall we term key factors in our analysis. Such factors comprise those aspects of a measure that lead to or are associated with "effectiveness, efficiency and appropriateness" and most likely to lead to or be associated with innovation within the target firms and more broadly.

In this review, as in the other reviews, we have been asked to identify those features that impact upon innovation. Many government measures including many in the area considered here of access to finance aim to give rise to growth and promote competitiveness, but they do not specifically aim to promote innovation as such. In fact few measures seek to promote innovation as their main outcome. We have therefore also sought to look at these measures for access to finance to see where they may lead to in the sense of indirectly causing innovation. This has allowed us to review a greater range of measures and to ensure that we cover measures that, while they may not directly target innovation, nevertheless have an important outcome in terms of promoting innovation. We have thus broadened our focus by considering measures that lead to new firm formation, to the support of firms that have growth or high prospects, and to firms that can be identified as having great propensity to or plans to develop specific intellectual property.

We carry out our assessment of the two forms of finance at the end of the report. We have also been attentive to the issue of capability development and structural issues that affect the demand and supply market failures that give rise, in particular, to the need for hybrid funds government subsidized equity investments. It has been claimed that a number of measures have real structuring effects in terms of improving the supply of equity capital. Where we have come across strong evidence of such an effect we show how such effects occur. Our review has not however focused explicitly on structuring effects.

We have focused our review on policies implemented at national level although we have taken account of international (e.g. OECD, European Union) initiatives for the support of SME financing through collaborative processes. There remain however, difficulties in pursuing common approaches when it remains the case that different countries employ quite different definitions of private equity / venture capital and loans, as the OECD is well placed to observe (OECD 2012).

\subsection{Venture Capital}

The scope of our review of evaluations that investigate and report on measures to support the venture capital system with the aim of promoting innovation is made more difficult because of the variety of measures adopted by countries, and recent history, which has created very different conditions for policymaking over a relatively short period of time. This has led to lack of comparability between measures and narrowed the scope for comparison of different periods of time as economic conditions have been varied greatly.

Furthermore, the "venture capital industry" is, as we make clear in our detailed analysis, a misnomer in that there is not a single industry providing capital to firms. Rather there is a series of markets for finance in which there are firms operating across many stages, but in general there are none that operate across all the different stages. Nevertheless, despite the fragmented nature of the market for capital for small businesses, there are some similarities between 
different business systems and countries for some lessons to be learned and to be applicable generally. We note also that while there are different stages of venture capital, those firms that are served by one stage, if they are successful and continue to grow, will be likely to draw upon successive stages at some point in the future. Thus it is important for policy makers to consider how their actions affect the chain of venture capital provision, not just one particular link.

A consequence for policy making to support the venture capital industry is that, as Meyer (2007) notes, government action can aim at a variety of targets and that while the general aim of government support is, as it is in the area of loan guarantees, to increase the availability of finance to small firms, there are in fact a wide range of options for support and different subsidiary goals, such as increasing social welfare, employment growth, or making changes to perceptions and capabilities of venture capital investors and thereby tackling the supply side problem of lack of investors in the market for venture capital.

\subsection{Scope for Credit Guarantee Schemes}

Credit Guarantee Schemes (CGSs) originated in Europe in the 19th and early 20th centuries and are now to be found in more than half of all countries, developed and developing, worldwide (Green 2003; World Bank 2008). Different types of schemes have evolved over time. In a large scale survey conducted by the World Bank, Beck et al. (2008) sampled 76 schemes operating in 46 countries and showed that there are large differences in the organizational features (ownership, management and funding structures) and rules of guarantee schemes around the world. Guarantee schemes sometimes focus on specific sectors, regions, or ownership groups, or on young or new technology firms (or even on firms that have been hit by an adverse shock and risk failure). Often there is a subsidiary employment, innovation, or productivity growth objective. Green (2003) identifies five major types of guarantee systems based on their operators: mutual guarantee associations, corporate schemes, those arising from bilateral or multilateral co-operation, schemes operated by NGOs and publicly supported or operated national schemes.

This report focuses on the latter - the publicly supported schemes. These schemes are usually managed by a private sector partner or a government administrative unit or agency. They involve a state subsidy particularly in the initial phases of operation and are well supported by the banking sector as, in the case of loan default, the guarantee is paid directly from the government budget (OECD 2008). The key question to resolve is whether publicly funded credit guarantee schemes are effective instruments for promoting lending to SMEs. The literature does not provide an unequivocal answer. Some authors (Llisterri 1997; Vogel and Adams 1997) have argued that CGSs are costly and give rise to problems of financial sustainability. Others argue that they can open up new lines of credit and can be effective under a well specified framework for their operations (Levitsky 1997). The empirical evidence is slim as there are only few studies that have addressed this issue in a systematic way. In this report we consider the recent evidence from several evaluations that have examined the effectiveness of CGSs in overcoming the main difficulties faced by SMEs in accessing the credit market. 


\section{Summary of findings}

\subsection{Review of Measures}

We have reviewed and synthesized the evidence of 16 studies of publicly supported venture capital and loan guarantees schemes and these studies are referred to in the tables 1 and 2 below. The tables capture the basic characteristics of the schemes and address their major impacts.

We start in the following subsection by discussing the publicly supported venture capital schemes.

\subsection{Publicly Supported Venture Capital: How effective are these initiatives?}

\subsubsection{Introduction}

Our review has made the following assumptions about the policy context in the area of support for venture capital. A) There is a pre-existing financing infrastructure comprising (family and friends, seed angels, and new and established venture capital investments etc) that fails to allocate significant financial resources for growth. B) These barriers give rise to a need for a range of government financial measures or instruments to support companies that do not manage to obtain the finance they need for continued operation and expansion. These financing instruments comprise equity guarantees, co-investment funds and venture capital funds. They can be directed at different parts of the venture capital system; for example, in recent years there has been some emphasis on supporting venture capital by subsidizing business angel networks (BANs), but earlier efforts to support small firms in need of capital were directed at increasing the supply of slightly later stage venture capital. C) These various instruments developed by government often in conjunction with the private sector support different parts of the venture capital process, and they also reflect the political and economic priorities of government. These priorities can be addressed through geographical and sectoral targeting and a focus on size of firm supported. D) Additionally, the instruments may set a risk level for the investment although this will be related to the financial partner, the type of instrument used and the priorities.

Our review of the impact of such measures seeks to answer the following questions which represent a set of ever more stringent tests of the effectiveness of the measures: a) do the measures increase the provision of equity capital for small firms; b) does the availability of finance result in changes within the firm that receives the financial assistance in terms of improvements in productivity, employment, and export performance; c) what level of additionality occur (if this has been measured) within the firm; d) what impacts upon innovation have arisen within the firm and beyond it (if measured); and e) finally, what impacts have occurred at the system level. The following discussion centres on these issues and attempts to indicate, for each test, relevant explanatory factors. These explanatory factors may include the venture capital segment that is the subject of the measures (i.e. Angel, Seed, Early Stage, Formative, Later Stage) but it may also include the management, organisation and operation of the measures, as well as business sector focus and geographical location of the measure. As we note later on in our comments on the systemic effects of venture capital support by government, the conditions faced by firms seeking financial support for growth and expansion (across the whole spectrum of venture capital) have varied enormously over the last 
two decades and this has made it difficult for policy makers to decide on policy goals and difficult for evaluators to determine impacts. The period has been once where the whole market for venture capital has boomed, with strong demand and strong supply. But there have been periods when there has been very little demand for resources and a very weak supply, in the socalled "nuclear winter" between 2001 and 2003, the period immediately following the dot-com bust. But there have also been periods when part of the market has worked well but other parts have fared badly (Yong-Protzel et al. 2007). During the 2004-2006 there was a "buy-out" boom where later stage capital was in good supply, but early stage firms were not well-served.

\subsubsection{Easing Access to Finance}

The provision of financial support by government through its various programmes of venture capital investment should allow more firms to access finance that are affected by market failures. Our review is clear that in this regard, the evaluations indicate that such measures have increased the availability of finance to firms. This is not to say that measures necessarily lead to additionality however.

We note however that access to venture capital appears to be very dependent upon proximity to venture capital firms and major urban centres. Those examining the problem of venture capital on a regional basis have become aware of the distinct decline in the availability of venture capital with increasing distance from major cities and in particular capital cities. This phenomenon of the "stickiness" of venture capital suggests that there are, within the regions, clear market failures for investment in the early stages of equity capital investment to which regional VC funds, rather than general, national or international commercial funds, are the answer Sunley et al. (2005). A paper comparing clustered with dispersed support to VC but without reporting findings on a specific scheme is Martin et al. (2002). Munari (2010) has examined the UK and has noted that the regional variations in venture capital are significant. His recommendation for policy is that government initiatives should target regional disparities to prevent those differences from being perpetuated and indeed made worse; but this is problematic because regions are by definition, distant from capital cities. The review of the UK's recent policy for regional venture capital - the Regional Venture Capital Funds - reveals very poor performance with the policy implication that funds should not be "constrained to regions" at all (Reid and Nightingale 2011, p. 20), although the analysis by Lerner et al. (2011) suggests that the very poor performance of the UK funds is not attributable entirely to the regional focus of funds.

While we are dealing with VC funding in this section, we feel we should note that the problem of financing business growth in the regions is likely to be one of ensuring that the right forms of financial assistance are available that match the local conditions. Thus, in areas where new firm formation produces firms that generally are avoided by VC organisations, debt financing for growth may be more suitable than government backed VC funds.

A further general point about the availability of venture capital is made in the study by Sunley et al. (2005). The authors suggest that access to finance is most critical for the firms at the earliest stages - just beyond angel investing stage. The initial policy response of the EU to financing at this level largely ignored this area (Mason and Harrison 1999). The equity gap that most affects technology firms (the subject of the study by Sunley et al. in their paper) is within the range 
from $£ 250 \mathrm{k}$ to $£ 750 \mathrm{~K}^{5}$. The implication of this finding is that the then cap on the investments made by the regional funds in the UK context should be raised to $£ 750 \mathrm{k}$.

Observation of the importance of the public sector within the overall provision of venture capital in the regions (mainly beyond London and the South East of England) in the UK has led Mason and Pierrakis (2009) to doubt the efficacy of public provision of venture capital without also addressing the demand side. One of their main conclusions is that regional funds are not likely to yield returns and generate growth unless the supply of high growth firms is enhanced, which will require greater use of demand side initiatives such of the kind operated in the US by the US Small Business Service (the Small Business Innovation Research (SBIR) Program) or in the UK the Technology Strategy Board's Small Business Research Initiative (SBRI).

\subsubsection{Impacts within the Firm: Productivity, Employment, Turnover, Exports}

It is notable that amongst the measures we have reviewed there are some which, while attempting to provide venture capital to firms have been directed towards the creation and preservation of employment.

It is perhaps not surprising that in the economy which has been longest in recession covered by this study - the Japanese economy - venture capital measures have been used to promote employment rather than growth. In Japan, the venture capital support has been modelled on the US Small Business Investment Company (SBIC) model ${ }^{6}$ but was found to have a relatively high bureaucratic load and few major investors are involved. The Japanese system has seen little targeting of small firms and potentially high growth firms, and VC funding has been used generally as recession protection insurance rather than as an attempt to create Schumpeterian "destruction" (Schaede 2005). In Canada, venture capital funding schemes have also been developed to support the economy in times of economic stress although the example covered by Ayayi (2004) is of a labour union sponsored scheme, not a government scheme.

Other schemes reviewed focus on such objectives as technology or output growth rather than employment. The Scottish Co-Investment Fund (SCF) evaluation has noted that the support given by co-investment has had greater effect on turnover than on employment (Centre for Strategy \& Evaluation Services 2008). The study by Murray (1998) however notes that investment in high technology firms has had a greater impact on employment than in non-high technology firms. This latter point is an interesting finding and is not consistent with the view, very widely held, that high growth firms - so-called gazelles - can be found in all sectors.

Studies not on a specific measure but instead companies that received various forms of private VC funding suggest further important focusing and selection mechanisms. In his study of firms in the CorpTech database, LiPuma (2006) notes the effect whereby venture capital investment restricts a firm's operation overseas. It may be the case that - and there are good ex ante reasons for believing this to be likely - venture capital places requirements upon firms that might not be present otherwise, for example, to commercialize their product more quickly. Such an effect, which would arise when the investing company seeks to secure a return upon its investment, would encourage firms to focus upon their home markets, rather than to internationalize.

\footnotetext{
${ }^{5}$ Currently the UK equity gap is defined as between $£ 250 \mathrm{k}$ to $£ 10$ million (HM Treasury 2003).

6 The US publicly supported fund for investing in small firms established in 1958.
} 
Two recent studies undertake a quantitative comparative assessment of impacts of publicly supported venture capital on firms. The first, using an instrumental variables estimator to control for selection bias is by Brander et al. (2010) who examined the differences between Canadian public (GVC) and private venture (PVC) capital investment on a range of outcomes related to value creation, competitive effects, and innovation. The study concludes that enterprises funded by GVCs tend to underperform on most outcome measures. They are less likely to have successful exits and, in particular, are much less likely to have IPOs on major exchanges. Furthermore, they generate lower exit values when they do have a successful exit. The GVCs invest less in high technology industries, and their enterprises generate fewer patents (even after controlling for industry selection). The study suggests there is no evidence that GVCs increase employment or competition. The second study along similar lines, Grilli and Murtinu (2012), examines the impacts of GVC versus independent venture capital (IVC) in a multi European country context. This study suggests GVC investment has no sizeable or significant effect on either the sales or employee/firm growth of European high-tech start-ups observed from 1993 to 2010 although there is some evidence of a sales impact when funding is syndicated but the governmental investor is subordinate to the private interest.

\subsubsection{The Additionality Dimension}

Evaluations that attempt to determine whether there is additionality at the level of the firm are not common and we were able to locate just seven that draw some form of contrast between firms supported and not supported. The study of Flanders support to Business Angel Networks (BANs) (Collewaert et al. 2008) uses a matching approach and is therefore more likely to discover the presence of a genuine net impact of the government initiative. The evaluation is inconclusive as regards performance improvements, in that short term impacts are negative although longer term ones may be positive. The study does not specifically focus upon innovation within the investee firms.

An interim evaluation of the Regional Venture Capital and Early Growth Funds (CI Research 2009) found from business and stakeholder surveys that both programmes provided funds to firms that were unlikely to attract private sector equity finance. The evaluation found businesses reported a wide range of benefits including the introduction of new products and services, entry into export markets and advice and guidance from Fund Managers. The majority of businesses experienced growth in employment and turnover, and attributed this to the investment of public funds.

\subsubsection{The Innovation Impact}

Very few of the evaluations that we have found are concerned directly or even indirectly with the innovation impact of venture capital support.

The review by Murray (1998) of the hybrid funds of the European Seed Capital Fund suggests that commercial funds were more likely to lead to innovation than regional public funds ${ }^{7}$. A subsidiary goal of the commercial funds reviewed in this study was that they sought to invest in new technology based firms. The evaluation did not look at the performance of the funds in relation to innovation specifically. However, the study reveals that investments in high

7 Investments with public money are increasingly channelled through commercial funds as a result of the adoption of the EU's Guidelines on State aid to support SME access to risk capital European Commission (2006). 
technology firms were more common in the general commercial funds than in the regional funds, despite the fact that the regional funds believed that they were investing more in technology firms than the commercial firms. Amongst the regional firms, the overall number of investments in firms that might be assumed to be high technology and therefore innovative was around $10 \%$ of the total firms. Importantly, the study found that higher technology firms (of which a majority asked for private instead of public money) were more likely to achieve higher growth in employment.

As we have noted above, the Japanese SBIC has sought to promote employment rather than innovation (Schaede 2005), and there are a significant number of schemes to increase the provision of venture capital that seek to support existing businesses rather than to create to sustain very new firms to deliver create innovation or growth. Policy makers in many countries, Japan is a good example but Canada (Ayayi 2004) is also a good case, have used venture capital funding instruments to support existing firms and have developed their schemes in periods of economic crisis. These policies protect existing firms rather than creating new firms.

Where there are schemes that focus on firms where technology innovation is likely to occur, one would expect these to give rise to innovation. However, there are confusing findings on this point. The review of Australian Pre-Seed Fund established in 2002, previously an Innovation Investment Fund (Australia) which had been operating since 1997 (Cumming 2007) has found that its investments are no more likely to be made in innovative and high technology companies than the average for a fund of this size, in spite of the fact that the rules of the fund management require investments into firms that are capitalizing upon and exploiting the scientific discoveries that have been made in universities and public laboratories or be connected to a grant (and that such firms be controlled by a university, public sector research agency or qualifying researcher or that they use intellectual property that is at least $50 \%$ owned by a university, public sector research agency or qualifying researcher). That a fund targeting what should be high technology firms should in practice give no more support to high technology firms than the typical fund may suggest problems with the management and operation of the fund (Jääskeläinen et al. 2007).

There is further a view that receives support from a number of writers that capital does not lead to innovation but that it merely supports commercialisation of existing innovations. This claim that financial resources follow innovation rather than leading to it - is an important one and it receives support from both economic modellers and scholars of the innovation process. Firstly, the economic modelling done by Engel and Keilbach (2007) suggests that VC investment leads not to innovation but to commercialisation, a view supported by Hellmann and Puri (2000). The difficulty is that these studies involve patent counts as the measure of innovation, also echoed by more recent studies, see for example Snieska and Venckuviene (2011). Engel and Keilbach's (2007) approach uses matching to ensure comparison of the treatment effect with relevant nontreated firms.

This approach is strongly supported by research by other qualitative researchers looking at innovation and finance. A recent paper by Tether and Stigliani (2012) suggests that "innovation", in terms of the creation of new ideas, if not products and processes, within the firm results less from the provision of financial capital and far more from the application of the creative and networking capabilities of a firm's owners. 
As we have noted above, the use of patent counts as the measure of innovation is problematic and may not be the best way of detecting whether venture capital causes innovation. As Engel and Keilbach (2007) accept, in their study of firms that received venture capital, those firms that received investment were ones that already had innovations in the form of patents. This, they say, suggests that venture capitalists choose to invest in firms that already have innovations rather than in firms that have yet to innovate but may be on the point of doing so. From the point of view of venture capitalists, a firm's intellectual property in the form of patents is an indicator of potential return that is likely to be a more closely associated with future performance than say a promise from the owners of the firm of future innovation activity.

\subsubsection{Fund Level Impacts}

The most important evaluation of UK schemes have examined the effectiveness of public support at the scheme level rather than at the level of the individual firm (NAO 2009; Lerner et al. 2011). These evaluations indicate that public funds are generally smaller in size and that they invest in fewer firms and the average size of their investments are smaller. Furthermore they realize gains (exits) less often and overall, their returns are significantly lower with the average IRR being 10 percentage points lower than the "average private fund in the UK and 6 percentage points lower in the US" although the large public-private returns gap diminishes slightly when controls for vintage year are introduced.

\subsubsection{Systemic Impacts}

As has been argued by the British Venture Capital Association and NESTA (2009), an important but hitherto neglected aspect of the design of studies that investigate VC funding policies of governments is that of the wider impacts of VC funding upon the economy and upon recipient firms. This approach is different from and could be said to run counter to the emphasis placed by the "inputs to the firm" perspective adopted by many finance oriented reviews of the VC capital policies of governments. However, few evaluations of programmes have been commissioned to investigate these broader - beyond input - effects of policy that are designated "entrepreneurship capital" within the capabilities perspective (Audretsch et al. 2008), or which investigate economy wide impacts on productivity growth.

The ideal case of the development through initial government support of an operational venture capital market that can ultimately function without support is that of Israel. Here, success has been attributed to the strong cultural and emotional bond with the US and the strong links between Israeli based entrepreneurs and foreign investors (Avnimelech and Teubal 2008; Jeng and Wells 2000). By contrast, Cumming (2011) argues that the systemic problems of VC investment generally are the result of government intervention in the market and that these problems do not constitute a rationale for investment but a warning against further government intervention.

Many of the government interventions that have been covered here seek to make immediate impacts upon firms and at the same time to achieve systemic change to the market for venture capital. The nature of changes to the system varies but the overall effect which is sought is that venture capital becomes more widely available and that the market failures on the supply side are reduced or removed.

The evaluation by Ryan (1990) of the Australian MIC Programme (Management and Investment Companies) stresses that the market for private equity is not a single homogenous market for 
risk capital and that the impact of any policy needs to be understood in terms of its outcome for the system as a whole. The Australian experience with the MIC and, following the failure of this initiative, the Pooled Development Funds (PDFs) (Harvie and Lee 2005), has not been positive as insufficient private investors have been available and the exit strategies for investors have been limited.

Recognition of the importance of very early stage finance within the overall venture capital system has led recently to the support of business angel networks in a number of countries. It is at this very early stage that the market failures are thought to be most pronounced and where action by government is most necessary. Work by Aernoudt et al. (2007) shows that some governments are prepared to provide loans to business angel networks for them to invest as equity in small firms. Those countries where there has been financial support for actual investments are Burges Equity Capital Guarantees (Austria); the Finnvera scheme (Finland); the Business Angels Wallonia (Belgium). There has been concern however that BANs ${ }^{8}$ may be too small to be effective and while they may achieve some additionality (Mason 2009) BANs are too small to be efficient. Development of the BAN concept such that BANs are now investment organisations offering opportunities to members which are vetted and prepared (i.e. a more service based approach is taken) appear to show promise (Collewaert et al. 2008). There are concerns though that as BANs increase the sizes of deals, they focus less on what public policy argues is where the real market failure exists, i.e. at the very earliest stages. As Mason (2009) notes however, the growth of privately operating BANs suggests that the evidence of market failure at this level of the investment cycle is not strong. In their article on the use of BANs, Aernoudt et al. (2007) note that BANs are supported by guarantees (which may be a confusing use of the term as the word guarantees are more often given in the context of loan finance).

Within Europe, the policy context for government action to provide venture capital (both EU and Member State) is provided by the EU Commission's communications on state aids for financing. This important framework sets limits to the amount of help which can be provided to firms. The Commission's statement from 2006 has now been superseded European Commission (2010) and the amount of public subsidy that Member States can provide in support has been raised. What the Commission regards as very poor financing conditions for very early stage investment has justified an up rating of the amounts available. The framework is of central importance to Member States which must abide by its rules on a range of topics; however, the framework is not one that defines innovation as such as a target: rather it is the existence of the market failures the specific policy instrument is planning to introduce that must be outlined and demonstrated.

\subsubsection{Other System Level concerns}

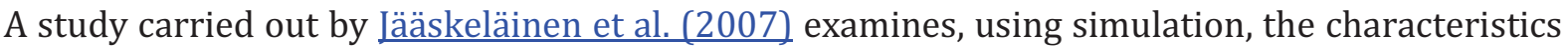
of hybrid funds (profit distribution and compensation structures) and attempt to define and identify the conditions under which early stage CV hybrid funds may operate profitably. The research has important conclusions for the operation of venture capital funds supported by government. One of their most important conclusions is that in the conditions of moderate and significant market failure, no design of hybrid fund of any kind can be achieved and that other measures beyond financing must be adopted: thus, schemes will fail "in the most difficult and

8 BANs are Business Angel Networks. They are private individuals who support private firms but they can be subsidized in their work by grants / awards from the government. 
problematic areas unless these schemes also have the effect of improving the quality of investors and subsequent gross returns". The authors continue: "As a consequence, governments will not be able to rely on such programs alone to improve the supply of earlystage finance. They are likely to have to address other related issues, in particular improving the framework conditions that will encourage the participation of more skilled and experienced entrepreneurs in key technology sectors" (Jääskeläinen et al. 2007, p. 927).

The review by Maula and Murray (2003) considers the connection between venture capital funding and other forms of support, such as capability building amongst investee firms, but also the $R \& D$ grant system and the export credit guarantee system. In Finland this system is operated by Finnerva PLC.

Other work (not peer reviewed) suggests the importance of the system as a whole and the need to consider a systemic approach to the development of policies to support the provision of venture capital (Meyer 2007) including the demand side (Mason and Pierrakis 2009). 
Table 1. Reviews of Venture Capital Support Measures

\begin{tabular}{|c|c|c|c|c|c|}
\hline \multicolumn{4}{|c|}{ Venture Capital Schemes } & \multicolumn{2}{|r|}{ Impact } \\
\hline $\begin{array}{c}\text { Country/ } \\
\text { Region }\end{array}$ & Study & Method & $\begin{array}{l}\text { Year/ } \\
\text { Perio } \\
\text { d }\end{array}$ & Access & Performance \\
\hline Australia & $\begin{array}{l}\text { Australian Pre-Seed } \\
\text { (Cumming 2007) }\end{array}$ & $\begin{array}{l}\text { Matched } \\
\text { comparison }\end{array}$ & $\begin{array}{l}2002 \\
- \\
2007\end{array}$ & $\begin{array}{l}\text { High tech firms } \\
\text { less likely to } \\
\text { receive funds } \\
\text { than general } \\
\text { funds of same } \\
\text { size }\end{array}$ & \\
\hline Australia & $\begin{array}{l}\text { Australia MIC (Ryan } \\
\text { 1990) }\end{array}$ & Review & 1990 & $\begin{array}{c}\text { Stresses } \\
\text { heterogeneity of } \\
\text { VC market for } \\
\text { finance } \\
\end{array}$ & \\
\hline Canada & $\begin{array}{l}\text { Government backed } \\
\text { VC (Brander et al. } \\
\underline{2010)}\end{array}$ & $\begin{array}{l}\text { Matching but } \\
\text { account taken } \\
\text { of selection } \\
\text { bias with } \\
\text { instrumental } \\
\text { variables }\end{array}$ & $\begin{array}{l}1996 \\
- \\
2004\end{array}$ & & $\begin{array}{l}\text { Exit, employment and } \\
\text { competition outcomes } \\
\text { assessed, }\end{array}$ \\
\hline Europe & $\begin{array}{l}\text { Euro Seed Capital } \\
\text { (Murray 1998) }\end{array}$ & Comparison & & $\begin{array}{l}\text { Regional firms } \\
\text { less likely to } \\
\text { invest in high } \\
\text { technology }\end{array}$ & \\
\hline Finland & $\begin{array}{l}\text { Maula and Murray } \\
\text { (2003) }\end{array}$ & Review & 2003 & $\begin{array}{l}\text { Structures and } \\
\text { variety of market } \\
\text { for VC }\end{array}$ & \\
\hline Flanders & $\begin{array}{l}\text { Flanders BANs } \\
\text { (Collewaert et al. } \\
\text { 2008) }\end{array}$ & $\begin{array}{l}\text { Matching } \\
\text { comparisons }\end{array}$ & & & $\begin{array}{l}\text { Inconclusive in short term, } \\
\text { possible impacts in long } \\
\text { term }\end{array}$ \\
\hline Flanders & Aernoudt et al. & $\begin{array}{l}\text { Matching } \\
\text { comparisons }\end{array}$ & & $\begin{array}{l}\text { Start of support } \\
\text { to BANs }\end{array}$ & \\
\hline Germany & $\begin{array}{l}\text { German VC Study } \\
\text { (Engel and Keilbach } \\
\text { 2007) }\end{array}$ & $\begin{array}{l}\text { Matched } \\
\text { comparison }\end{array}$ & & & $\begin{array}{l}\mathrm{VC} \text { is post innovation } \\
\text { phenomenon }\end{array}$ \\
\hline Israel & $\begin{array}{l}\text { Yozma (Avnimelech } \\
\text { and Teubal 2002) }\end{array}$ & Review & 2000 & $\begin{array}{l}\text { Self-sufficiency } \\
\text { and persistence } \\
\text { of effects once } \\
\text { public funding } \\
\text { withdrawn }\end{array}$ & \\
\hline Japan & $\begin{array}{l}\text { Japanese SBC } \\
\text { (Schaede 2005) }\end{array}$ & Review & & & $\begin{array}{l}\text { Employment effects higher } \\
\text { than turnover and growth }\end{array}$ \\
\hline N.A. & $\begin{array}{l}\text { Simulation Study on } \\
\text { Systemic Effects } \\
\text { (Jääskeläinen et al. } \\
\underline{2007)}\end{array}$ & Simulation & 2007 & $\begin{array}{l}\text { Simulation: } \\
\text { demonstrates } \\
\text { need for high } \\
\text { quality investors, } \\
\text { implications for } \\
\text { demand side }\end{array}$ & \\
\hline Scotland & $\begin{array}{l}\text { Scottish Co- } \\
\text { Investment Fund } \\
\text { (Centre for Strategy } \\
\text { \& Evaluation } \\
\text { Services 2008) }\end{array}$ & $\begin{array}{l}\text { Comparisons } \\
\text { and Matched } \\
\text { Pairs }\end{array}$ & 2008 & & $\begin{array}{l}\text { Turnover improves, } \\
\text { employment effects are } \\
\text { less; infrastructure } \\
\text { changes occur }\end{array}$ \\
\hline UK & $\begin{array}{l}\text { Regional VC (Munari } \\
\text { 2010) }\end{array}$ & $\begin{array}{l}\text { Matched } \\
\text { Pairs }\end{array}$ & 2010 & $\begin{array}{l}\text { Declining } \\
\text { strongly with } \\
\text { distance }\end{array}$ & \\
\hline
\end{tabular}




\begin{tabular}{|c|c|c|c|c|c|}
\hline \multicolumn{4}{|c|}{ Venture Capital Schemes } & \multicolumn{2}{|r|}{ Impact } \\
\hline $\begin{array}{c}\text { Country/ } \\
\text { Region }\end{array}$ & Study & Method & $\begin{array}{l}\text { Year/ } \\
\text { Perio } \\
\text { d }\end{array}$ & Access & Performance \\
\hline UK & $\begin{array}{l}\text { Regional VC Funds } \\
\text { (Mason and } \\
\text { Pierrakis 2009) }\end{array}$ & Review & 2009 & Demand Side & \\
\hline UK & $\begin{array}{l}\text { Tether and Stigliani } \\
\text { (2012) }\end{array}$ & Review & $\begin{array}{l}2000 \\
- \\
2008\end{array}$ & & $\begin{array}{l}\text { VC funding may follow } \\
\text { innovation and is "post- } \\
\text { patent": i.e. innovation is } \\
\text { not caused by funding }\end{array}$ \\
\hline UK & $\begin{array}{l}\text { UK (BIS) Venture } \\
\text { Capital Funds (NAO } \\
\underline{\text { 2009) }}\end{array}$ & & $\begin{array}{l}2000 \\
- \text { to } \\
2009 \\
\text { (vari } \\
\text { ous } \\
\text { funds }\end{array}$ & & $\begin{array}{l}\text { Poor performance of } \\
\text { public versus relevant } \\
\text { comparator private funds; } \\
\text { generally poor } \\
\text { performance and fund } \\
\text { design key factor leading } \\
\text { to very poor performance }\end{array}$ \\
\hline US & $\begin{array}{l}\text { CorpTech Database } \\
\text { (LiPuma 2006) }\end{array}$ & $\begin{array}{l}\text { Comparison } \\
\text { (Step IV) }\end{array}$ & 2003 & & $\begin{array}{l}\text { VC support (not public) } \\
\text { reduces likelihood of } \\
\text { internationalization }\end{array}$ \\
\hline
\end{tabular}

\subsection{Loan Guarantees: How effective are CGS?}

\subsubsection{Introduction}

The primary purpose of guarantee schemes is to expand availability of credit to SMEs. There is a general perception that SMEs are seriously disadvantaged in financial markets. With fewer assets and lacking a track record, small firms experience tighter financial constraints from the banking sector compared to other firms (Zecchini and Ventura 2009). In a debate spanning almost 4 decades, various authors (Green 2003; Roper 2011) suggest that this is due several factors including high administrative costs of small-scale lending, asymmetric information, inadequate collateral and the overall riskiness of these early stage businesses. Such constraints can impact negatively on the potential for SMEs long-term growth and development through under-investment, reduced productivity and lower growth rate as well as lead to a waste of entrepreneurial resources.

\subsubsection{Issues of Additionality}

The issue of additionality is central to evaluating the performance of CGS and has long been considered the acid test of effectiveness. Additionality is usually defined as SME loans facilitated through the guarantee scheme that would not have been otherwise available in the credit market (Boocock and Shariff 2005). However, there is a wide interpretation of what this means in the literature. Some measures focus on financial issues: longer term financing instead of short term, financing of intangible assets or of sectors or types of project previously excluded (Saadani et al. 2010; see also Meyer and Nagarajan 1996). Other forms of additionality also take account of the developmental impact of the scheme, including the survival rate of firms, investment, growth, and job creation.

The identification and measurement of additionality is not a straightforward exercise and has been a central concern of the literature since the late 1980s (Levitsky and Prasad 1987). Vogel 
and Adams (1997) question the effectiveness of the early evaluations of credit guarantee schemes. They identify two sets of problems. The first relates to the counterfactual: it is impossible to know what the lender would have done in the absence of the loan guarantee program. The second relates to measurement consequences arising from intra-portfolio substitution. Such situations can occur when lenders make multiple loans to borrowers to ensure that they fit under loan ceilings specified by the guarantee program; or, perhaps redefine the purpose of existing loans to qualify borrowers for the loan guarantee. If lenders take advantage of guarantee programmes in such ways the accuracy of measuring additionality will be compromised.

The assessment of additionality is technically challenging (World Bank 2008; Saadani et al. 2010) but in recent years studies across different countries have found that guarantee schemes generated, in some cases, significant additionality. A cross country comparison of different schemes presents a number of hurdles for the researcher to overcome as there are differences in organization, coverage and objectives of schemes. Roper (2011) notes that while some schemes are designed primarily to augment the financing available to small firms (e.g. Canada, France and the UK) in others, such as SBA programme in the US, firms need to prove that they were unable to obtain funding from other sources. Differences also exist with respect to how schemes are organized and who is responsible for the loan decisions. The Canadian scheme for example assumes full responsibility for loan decisions while in France and Korea guarantee funds review applications directly (Saadani et al. 2010).

Some of the early evaluations of guarantee schemes used qualitative assessments of bankers and user firms to determine whether they led to an improvement in credit availability for SMEs. One well-known attempt to evaluate additionality was undertaken by KPMG (1999) in their analysis of the UK Small Business Loan Guarantee Scheme (Riding et al. 2007). The KPMG study took a dual approach to measuring additionality. The first was a series of aligned interviews' with borrowers and their respective loan account managers while the second drew on a survey of owners of the firms that had received guaranteed loans. While interview programmes may be useful in terms of learning about lender borrower relationships, it is doubtful whether statistically valid conclusions can be inferred from just the characteristics of the sampled firms participating in the scheme. Nevertheless, the KPMG study concluded that $70 \%$ by number of firms, or around $60 \%$ of the total value of loans, were considered to be additional. Boocock and Shariff (2005) followed a similar method to measure the effectiveness of Malaysia's guarantee scheme through a postal questionnaire survey and 15 detailed case studies of beneficiaries of the scheme. Their analysis of the latter showed that the scheme resulted in 37\% additional funding, a value that was substantially lower than the $54 \%$ obtained through the questionnaire to a larger set of beneficiaries. In contrast to asking borrowers about whether or not they would receive a loan otherwise a study by Saldana (2000) (cited in Honohan (2010)) for the Philippines, estimated additionality by counting only those loans with collateral below the level of total loan value. Only around half of the loans guaranteed in the Philippines scheme satisfied the collateral criteria although it would be difficult to argue that less than fully collateralized loans is a convincing measure of additionality. 


\subsubsection{An overview of the evaluation evidence}

In contrast to the qualitative approaches discussed above in this subsection of the report we present the main findings from 8 recent studies that assess additionality of CGSs by comparing user firms' financial and or economic performance with a control group of firms - non-users of the respective schemes. However impacts are difficult to evaluate with a control group approach due to the potential for selection bias. A popular approach used by several of the evaluations counteracts the selection bias by combining difference-in-differences methods with propensity score matching techniques to ensure the similarity between participants and nonparticipants. Table 2 gives a summary overview of the studies (see Appendix for brief descriptions of schemes). While each study approaches the analysis from slightly different perspectives, in aggregate they focus on investigating three interrelated issues: improved access to credit; impacts on firm performance and default rates. These issues are discussed in turn below.

Table 2. Review of Loan Guarantee Support Measures

\begin{tabular}{|c|c|c|c|c|c|c|}
\hline \multicolumn{4}{|c|}{ Guarantee Schemes } & \multicolumn{3}{|c|}{ Impacts } \\
\hline Country & Study & Method & Year/Period & Access & Performance & Default \\
\hline Canada & $\frac{\text { Riding et }}{\text { al. (2007) }}$ & PSM & 2000 & Yes & n.c. & n.c. \\
\hline Chile & $\begin{array}{l}\text { Cowan et } \\
\text { al. (2008) }\end{array}$ & PSM; DiD & $2003-2006$ & Yes & n.c. & Yes \\
\hline Colombia & $\begin{array}{l}\text { Arraiz et } \\
\text { al. (2011) }\end{array}$ & PSM; DiD & $2002-2007$ & n.c. & $\begin{array}{l}\text { Output + } \\
\text { Emp - } \\
\text { Prodv. n.e. } \\
\text { Invest. n.e. }\end{array}$ & n.c. \\
\hline France & $\begin{array}{l}\text { Lelarge et } \\
\text { al. (2008) }\end{array}$ & $\begin{array}{l}\text { Quasi- } \\
\text { Natural } \\
\text { experiment }\end{array}$ & $1995-2000$ & Yes & $\begin{array}{l}\text { Cap + } \\
\text { Emp + }\end{array}$ & Yes \\
\hline Italy & $\begin{array}{l}\text { Zecchini \& } \\
\text { Ventura } \\
\underline{\text { (2009) }}\end{array}$ & PSM; DiD & $2000-2004$ & Yes & $\begin{array}{l}\text { Output + } \\
\text { Emp + }\end{array}$ & n.c. \\
\hline Japan & $\begin{array}{l}\text { Uesugi et } \\
\underline{\text { al. }(2010)}\end{array}$ & PSM; DiD & 2001-2005 & Yes & Profit - & Yes \\
\hline Korea & $\frac{\text { Oh et al. }}{(2009)}$ & PSM; DiD & $2000-2003$ & n.c. & $\begin{array}{l}\text { Output + } \\
\text { Emp - } \\
\text { Prodv. n.e. } \\
\text { Invest. n.e. }\end{array}$ & Yes \\
\hline UK & $\begin{array}{l}\text { Cowling } \\
\text { (2010) }\end{array}$ & PSM; & $2006-2008$ & Yes & $\begin{array}{l}\text { Output + } \\
\text { Emp + } \\
\text { Prodv. + }\end{array}$ & Yes \\
\hline
\end{tabular}

Notes:

n.c. $=$ not considered

PSM = Propensity Score Matching

DiD= difference in difference estimation

Performance variable + or $-=$ significant positive or negative impact

Performance variable n.e. $=$ no effect 


\section{Does the intervention bring about improved access in credit markets for SMEs?}

Even a cursory glance at the table shows that the majority of studies found that schemes improved access to credit finance. But the manner in which this was analyzed and the degree of additionality differed on a case by case basis. Riding et al. (2007) for example exploited data from a large scale survey of SMEs borrowing experiences to assess the additionality of the Canadian Small Business Financing (CSBF) programme by using a credit scoring methodology to estimate a loan turndown model. The first stage used a sample of 292 applications to commercial lenders for term loans. Although these firms were eligible for CSBF financing, they had not applied for guaranteed loans. Data on the known outcomes of this sample were used to derive the parameters and properties of a statistical model that distinguished between the two outcomes. This model was then used to predict how many of those firms that successfully applied under CSBF scheme would have been denied finance in the credit market. Based on their estimates, Riding et al. (2007) conclude that $75 \%$ of firms that actually received credit under the CSBF would not have qualified for loans in the credit market.

For Italy's state funded guarantee scheme (SGS), Zecchini and Ventura (2009) argued that debt levels between guaranteed and non-guaranteed firms is consistent with a lending additionality test. Credit rationed firms (without guarantees) should a priori have lower debt levels relative to guaranteed firms and this is equivalent to the additional supply of credit. They applied a difference in difference analysis and showed that the median value of bank debt was higher by $12.4 \%$ for guaranteed firms relative to the others. While admitting such value was on the low side compared to other studies, Zecchini and Ventura (2009) suggest that this evidence correlates with the high degree of selectivity in targeting SME groups in Italy and, when compared to other examples, the Italian SGS scheme had historically managed to limit default rates and contain the public subsidy. In addition, the guarantee enabled participating firms to reduced borrowing costs between $16 \%$ and $20 \%$ at the median point compared to nonguaranteed firms. Similar financial indicators were used by Uesugi et al. (2010) in considering the availability problem in their analysis of the performance of Japan's Special Credit Guarantee facility between 1998 and 2001. While they found that relative to non-participants, there was increase in the availability of loans for users of the scheme, the difference, although statistically significant was of the order of $2 \%$ to $3 \%$.

In the case of the French loan guarantee program (SOFARIS) a change of eligibility rules in 1995 enabled Lelarge et al. (2008) to compare changes in the newly eligible firms after the regulation to changes in a large sample of control firms. The logic of their argument is simple. If firms are credit constrained then they should benefit from more favourable borrowing conditions and are expected to be more highly leveraged. On the other hand if they are not credit constrained and still apply to the programme for windfall benefits from lower interest rates then guarantee firms would not be characterized by higher levels of debt but by a lower financial burden (interest rates). The analysis found evidence of credit additionality as newly eligible firms were able to raise more external finance. After controlling for firms' initial debt levels, the growth of bank debt of guaranteed firms was $6.9 \%$ higher than for the control group; moreover, this was accompanied by a decline in debt burden as rates short run interest rates fell relative to the control group.

As a final example, consider the most recent evaluation of the UK Small Firms Loan Guarantee scheme (SFLG). Cowling (2010) used propensity scoring to construct a counterfactual group against which to compare the performance of SFLG supported firms. Both the treated and 
control groups were then surveyed to collect information on various aspects of performance. However the measurement of additionality was based on self-reporting. Only 6 per cent of SFLG borrowers indicated that their bank would have given them a loan without SFLG, and a further 15 per cent suggested that this was a probable outcome. Thus 79\% of SFLG loans were considered additional although it is not possible to assess whether business owners' judgement was correct about not being able to access conventional loans.

\section{Does the extra access to credit impact on firms' performance?}

Supporting credit constrained SMEs through easing investment funds has the potential to deliver economy wide productivity increases through their impact on investment, enterprise and innovation. Several of the studies considered how access to credit impacted on firm performance by considering impacts on a number of variables including output, employment, investment and productivity.

Arraiz et al. (2011) examined the impact of program participation on firm performance of the National Guarantee Fund (NGF) in Colombia. They argue that if access to financing was a binding constraint on firm growth and NGFs credit guarantees succeeded in removing it, treated firms should outperform comparable firms not benefitting from the program. They found that the relaxation of the credit constraints resulted in the growth of beneficiary firms, both in terms of employment (4.6\%) and output (5.8\%) relative to their counterparts in the control group. However rather disappointingly, they could find no evidence that the use of NGF credit guarantees resulted in higher investment rates or improved productivity. But based on these latter results, they suggest that firms use the guarantee programme to increase their working capital rather than to invest in fixed assets.

The impact of Korea's two schemes, the Korea Credit Guarantee Fund (KCGF) and the Korea Technology Credit Guarantee Fund (KOTEC), was analysed by comparing the performance of firms funded by these programmes and a control group of other firms for the period 2000 to 2003. Oh et al. (2009) considered a number of dimensions: growth in TFP, employment, sales, wage level investment intensity and change in R\&D status and survival. Overall their analysis shows that compared to unsupported firms, the policy had a positive effect on the growth of sales, employment and wage levels. Along these dimensions, the performance of KOTEC firms was stronger relative to the control group than KSGF firms $(26.9 \%, 8.5 \%$ and $8.2 \%$ for KOTEC firms compared to $16.3 \%, 5.6 \%$ and $3.3 \%$ for KCGF firms). However compared to the control group, there was no evidence that the schemes had positive effects on productivity growth, R\&D or investment intensity. Such an outcome, Oh et al. (2009) suggest, is as a result of the schemes supporting lower productivity firms to increase their size and probability of survival in the aftermath of the Asian financial crisis.

For the French SOFARIS programme, Lelarge et al. (2008) focused on firms' employment and capital growth. Guarantee firms experience a 25\% (OLS estimates) higher employment growth rate in the short run (0-2 years) and, if they survived (0-6 years), 16\% in the long run. The increased debt capacity due to participation in the guarantee scheme can result in investment and faster capital growth. After controlling for initial size, guaranteed firms were able to achieve a capital growth rate in excess of $50 \%$ both in the short and long run.

Cost benefit analysis showed that the UKs SFLG supported businesses generated substantial levels of additional sales and jobs compared to what would have happened in the absence of the 
programme (Cowling 2010). The evidence indicates that firms supported through SFLG lending achieve similar performance levels to those able to access conventional bank loans and the wider business population in general. While on the surface labour productivity among SFLG supported firms grew by an average of $63 \%$ compared to $59 \%$ for non-supported firms and SFLG firms' sales turnover increased by $138 \%$ between 2006 and 2008 compared to $66 \%$ in a non-borrowing comparison group, after controlling for sample characteristics, there were no significant differences between these averages. In addition, firms that participated in the SFLG schemes were $65 \%$ more like to export than the comparator group, $17 \%$ more likely to use new technology and $24 \%$ more likely to use 'cutting edge' technology.

\section{To what extent do schemes affect default rates?}

The default rate is one of the conventional indicators of a scheme's performance. A high default rate raises concerns about whether there are inefficiencies in the scheme that favour poor credit propositions but equally important it might be a signal that loan guarantees leads to more risk taking both on the part of businesses and the banks (the moral hazard argument).

Lelarge et al. (2008) estimate the probability of bankruptcy for the SOFARIS scheme and found that there was a significant and sizable increase in default probability which increased from $6 \%$ in the first two years after the guarantee to $29 \%$ over the long term (0-6 years). One of the possible explanations of this is that an important feature of the SOFARIS is that banks are not allowed to request additional private guarantee for loans backed by SOFARIS. Thus borrowers effectively have a limited liability and this creates risk shifting incentives. A complementary argument is that banks have lower incentives to monitor SOFARIS backed loans and the borrower anticipates this behaviour and adopts riskier strategies.

A similar argument could be applied in the case of the Special Credit Guarantee (SGS) facility of Japan between 1998 and 2001 where there was 100\% coverage of default costs. Uesugi et al. 2010) found that the performance of program users deteriorated relative to non-users. SGS users experienced lower profitability, with return on assets being less than comparable firms by between -0.3 and $-0.5 \%$. Moreover they also appeared to have a higher probability of financial problems as the number of user firms with a profit to interest payment ratio less than one exceeded by between $3 \%$ and $7 \%$ that the control group. As a consequence of declining profitability there was an increase in insolvency and defaults among the SCG users. Such evidence, Uesugi et al. (2010) suggest, supports a hypothesis of moral hazard problems rather than one of an investment effect and the severity of the moral hazard problem was shown to be related to the net worth of the firm. For programme users the lower the capital levels the higher the probability of default and insolvency relative to non-users.

Drawing on the Chile's Partial Credit Guarantee Fund (FORGAPE) Cowan et al. (2008) argues that by effectively lowering collateral requirements, guarantee schemes not only reduce risk exposure but may distort banks incentives to screen and monitor firms investment decisions. The latter has the potential to offset any benefits that improvements in credit access bring to the economy. The default rate of a guaranteed loan can be as much as $8 \%$ higher than the default rate of similar non-insured loan. Clients with insured and uninsured loans in the same banks have a higher default rate $(1.6 \%$ after 1 year and $5 \%$ after 2 years $)$ on their insured loans compared to their uninsured loans. Further for the same levels of sales and assets, clients with insured commercial loans have a higher default rate (1.9\% after 1 year and $4.2 \%$ after 2 years) on commercial loans than similar entrepreneurs with uninsured commercial loans. Cowan et al. 
(2008) suggest that the provision of the guarantee affect the banks' monitoring incentives thus causing banks to allocate less effort to collecting insured loans.

\section{Lessons and Conclusions}

\subsection{General}

Government policy for venture capital and loan guarantees are used to supplement the availability of finance for development and growth. Instruments to provide finance are available from both the private sector and the public sector. Public sector instruments are focused on small and medium enterprises (SMEs). Government supports these firms because of market failures in the provision of finance to these kinds of firm.

Very few initiatives are specifically directed at causing innovation as such. Support in the form of venture capital assistance or loan guarantees is intended in the first instance to provide the resources that firms need to grow. Programme designers expect access to finance to lead to increases in turnover and employment which will accompany innovation.

While it has been assumed that venture capital leads to innovation, there are studies of various kinds including one with a matched-pairs design and another with a qualitative approach, that suggest innovation occurs before finance from either venture capital investors or from banks is provided.

Evaluations conducted on these measures employ a range of approaches to assess performance, some of which are simply descriptive, some of which involve comparisons but very few of which attain the level that can control for the selection bias effects ${ }^{9}$ that would help to measure the net impacts of policy.

Evaluations can be divided into two main groups according to their unit of analysis. There are evaluations that look at the level of funds which invest in firms or which loan money with government guarantees, and evaluations that look at the level of performance of firms that receive help, either in the form of capital injection or loans. Evaluations at the level of funds cannot consider additionality at firm level. There are few studies that attempt to examine what the larger scale impacts of these initiatives are in terms of growth of employment and improvements to productivity across the economy.

\subsection{Venture Capital}

Some of the main points that emerged from the review of venture capital schemes are as follows.

- A number of measures seek to promote innovation but in some cases the schemes have been designed and implemented in such a way as to protect firms. This may weaken selection pressures.

- Few venture capital scheme reviews carry out comparison using matched pairs and account explicitly for selection bias.

\footnotetext{
${ }^{9}$ Storey's Step 6 in his Six Steps to Heaven (Storey 1999).
} 
- Evaluation of venture capital schemes show few schemes aim directly to cause "innovation" as such.

- Impacts of programmes assessed are usually employment and turnover, with some consideration given to export performance (internationalization) in some schemes. Patenting is also considered in a small number of evaluations.

- Some venture capital programmes are very concerned with the creation of systemic effects. Systemic effects are where programmes seek to improve the private capability in the area of investment, i.e. the supply side, with a view to increasing the overall level of funds available for investment, thereby removing or ameliorating the market failure. This is because the investment infrastructure is less easy to preserve and is especially likely to decline in effectiveness during periods of economic difficulty. Some evaluations consider systemic effects on the demand side to be required to solve the problem of the low number of new firms created ${ }^{10}$ and the low growth rate of firms.

- While some of the evaluations we have examined have been attentive to the impact of finance upon innovation, an issue that we interpreted as at the core of this report, no work has taken the broad and long term economic impacts of the innovations thus funded into account. We therefore do not have a good sense of how important this form of funding is in terms of major impacts upon the economy. More fundamental lessons could be learned therefore about the economic impacts by widening the scope from innovation to commercialisation of innovation. We note that evaluations of schemes that take these effects into account have not been possible to find.

\subsection{Credit Guarantees}

With respect to publicly supported credit guarantee schemes, we note the following points:

- Credit guarantee schemes have not been particularly directed to supporting innovation activities and of the studies considered innovation has been the focus of attention of the KOTEC scheme in Korea.

- To the extent that there was credit rationing, credit guarantee schemes have contributed to relaxing this constraint for SMEs in many countries and in different economic climates.

- Credit guarantee schemes help businesses to grow. Several evaluations show a direct causal effect on output (sales) and employment. However the evidence when considered also indicates that some schemes did not impact of firm productivity, R\&D or investment intensity. In such circumstances schemes may actually be supporting struggling firms and ultimately stifling innovative forces. 
- While metrics such as default rate and economic or financial additionality provide evidence about the performance of schemes, better comparisons are not possible as there is no consistent standard for measurement of the schemes.

\subsection{Common Issues and Final Observations}

One of the common concerns in our analysis of venture capital support and credit guarantees is the issue of moral hazard. Credit guarantee schemes reduce the incentive and commitment of borrowers to repay loans. Evidence shows that even in the most 'careful' schemes borrowers adopt risky strategies. Moral hazard exists on the part of banks also as studies have shown that in some cases there was less incentive to supervise loans properly. Moral hazard also affects venture capital support measures that have government support. Evaluations of government supported venture capital funds show the importance of the design of the compensation arrangements in the sharing of risk between investing bodies and those organisations in which investments are made.

The a priori assumption, which we ourselves have not made but which others may have done, that these two forms of government backed financial assistance would lead equally to innovation within the firm and the economy is difficult to establish with the evidence provided by the studies we have evaluated. Moreover, these two forms of financial assistance do have different purposes in that they support firms at different stages of their evolution, and we would expect VC support schemes would target firms at the pre-market and more risky phase of development than credit guarantees. 


\section{References}

Aernoudt, R., San Jose, A., Roure, R. (2007). "Executive Forum: Public Support for the Business Angel Market in Europe - a Critical Review." Venture Capital 9(1): 71-84.

Akerlof, G. (1970). "The market for lemons: quality uncertainty and the market mechanism." Quarterly Journal of Economics 84: 488-500.

Arráiz, I., M. Meléndez, \& R. Stucci (2011). "The Effect of Partial Credit Guarantees on Firm Performance: the Case of the Colombian National Guarantee Fund."

Arrow, K. (1974). The Limits of Organisation. New York: Norton.

Audretsch, D. B., Bönte, W. \& Keilbach, M. (2008). "Entrepreneurship capital and its impact on knowledge diffusion and economic performance." Journal of Business Venturing 23(6): 687-698.

Avnimelech, G. and M. Teubal (2002). Venture capital policy in Israel: A comparative analysis and lessons for other countries. Jerusalem: Department of Economics, Hebrew University of Jerusalem.

Avnimelech, G. and M. Teubal (2008). "From direct support of business sector R\&D/innovation to targeting venture capital/private equity: a catching-up innovation and technology policy life cycle perspective." Economics of Innovation and New Technology 17(1-2): 153-172.

Ayadi, R. (2005). The new Basel Capital Accord and SME financing: SMEs and the new rating culture, Brussels: CEPS,

Ayayi, A. (2004). "Public Policy and Venture Capital: The Canadian Labor-Sponsored Venture Capital Funds." Journal of Small Business Management 42(3): 335-345.

Beck, T., L. F. Klapper, \& J. C. Mendoza (2008). "The Typology of Partial Credit Guarantee Funds around the World." World Bank Policy Research Working Paper No 4771.

Berger, A. N. and G. F. Udell (2004). A More Complete Conceptual Framework for SME Finance. World Bank Conference on Small and Medium Enterprises: Overcoming Growth Constraints World Bank, MC 13-121 October 14-15, 2004.

Besanko, D. and A. V. Thakor (1987). "Collateral and Credit Rationing: Sorting Equilibria in Monopolistic and Competitive Credit Markets." International Economic Review 28(3): 671-689.

Bessant, J. and J. Tidd (2007). Innovation and Entrepreneurship. Chichester: Wiley \& Sons.

Bester, H. (1985). "Screening vs Rationing in Credit Markets with Imperfect Information." American Economic Review 75(4): 850-855.

BIS (Department of Business, Innovation and Skills) (2009). The provision of growth capital to UK small and medium sized enterprises. Norwich: TSO.

BIS (Department of Business, Innovation and Skills) (2012). SME access to external finance. BIS Economics Paper No. 16.

Boocock, G. and M. N. S. Shariff (2005). "Measuring the effectiveness of credit guarantee schemes: Evidence from Malaysia." International Small Business Journal 23(4): 427-454.

Brander, J. A., Edward J. Egan, and Thomas F. Hellmann (2008). Government Sponsored versus Private Venture Capital: Canadian Evidence. NBER Working Paper No. 14029. May 2008.

Brander, I. A., Edward Egan, Thomas F. Hellmann (2010). Government Sponsored versus Private Venture Capital: Canadian Evidence, In: I. Lerner and A. Schoar, eds., International Differences in Entrepreneurship. Chicago, IL: University of Chicago Press.

British Venture Capital Association and NESTA (2009). From funding gaps to thin markets: UK Government support for early-stage venture capital.

Caselli, S., G. Stefano, F. Perrini (2009). "Are Venture Capitalists a Catalyst for Innovation?" European Financial Management 15(1): 92-111.

Centre for Strategy \& Evaluation Services (2008). Evaluation of ERDF Supported Venture Capital and Loan Funds. Edinburgh.

CI Research (2009). RVCF and EGF Interim Evaluation: Recipient Business and Stakeholder. Surveys Summary Paper URN 09/1578. 
Collewaert, V., S. Manigart, \& R. Aernoudt (2008). "Assessment of Government Funding of Business Angel Networks in Flanders." Regional Studies 44(1): 119-130.

Cowan, K., A. Drexler, Á. Yañez (2008). "The effect of credit insurance on liquidity constrains and default rates: Evidence from a Government Intervention." Central Bank of Chile Working Papers No 524.

Cowling, M. (2010). "Economic Evaluation of The Small firms Loan Guarantee (SFLG) Scheme."

Cowling, M. and P. Mitchell (2003). "Is the Small Firms Loan Guarantee Scheme Hazardous for Banks or Helpful to Small Business." Small Business Economics 21(1): 63-71.

Cumming, D. (2007). "Government policy towards entrepreneurial finance: Innovation investment funds." Journal of Business Venturing 22(2): 193-235.

Cumming, D. (2011). "Public policy and the creation of active venture capital markets." Venture Capital: An International Journal of Entrepreneurial Finance 13(1): 75-94.

EKOSGEN (2011). BIS Equity Finance Programmes Qualitative Reviews of: a) UKHTF and B) The Bridges Fund.

Engel, D. and M. Keilbach (2007). "Firm-level implications of early stage venture capital investment - An empirical investigation." Journal of Empirical Finance 15: 150-167.

European Commission (2006). Community guidelines on state aid to promote risk capital investments in small and medium-sized enterprises (2006/C 194/02; Text with EEA relevance).

European Commission (2010). Communication from the Commission amending the Community guidelines on State aid to promote risk capital investments in small and medium-sized enterprises.

Evans, D. S. and B. Jovanovic (1989). "An estimated model of entrepreneurial choice under liquidity constraints." Journal of Political Economy 97: 808-827.

Gompers, P. and J. Lerner (2001). "The Venture Capital Revolution." The Journal of Economic Perspectives 15(2): 145-168.

Green, A. (2003). "Credit Guarantee Schemes for Small Enterprises: An Effective Instrument to Promote Private Sector-Led Growth?" SME Technical Working Papers Series, Working Paper No 10, UNIDO, Vienna.

Grilli, L. and S. Murtinu (2012). Government, Venture Capital and the Growth of European HighTech Start-Ups: A Firm-Level Panel Data Analysis. (May 25, 2012). Available at SSRN.

Harvie, C. and B. C. Lee, Eds. (2005). Sustaining Growth and Economic Performance in East Asia: Studies of Small and Medium Enterprises in East Asia, Volume III. Cheltenham: Edward Elgar.

Hellmann, T. and M. Puri (2000). "The interaction between product market and financing strategy: the role of venture capital." The Review of Financial Studies 13(4): 959-984.

Hirukawa, M. and M. Ueda (2008). "Venture Capital and Industrial Innovation, CEPR Discussion Papers 7089." Centre for Economic Policy Research.

HM Treasury (2003). "Bridging the Finance Gap: next steps in improving access to growth capital for small businesses."

Honohan, P. (2010). "Partial credit guarantees: Principles and practice." Journal of Financial Stability 6(1): 1-10.

Institute of Chartered Accountants of England and Wales (2010). Private Equity Demystified: An explanatory guide, Second edition.

\ääskeläinen, M., M. Maula, \& G. Murray et al. (2007). "Profit distribution and compensation structures in publicly and privately funded hybrid venture capital funds." Research Policy 36(7): 913-929.

Jaffe, A. B. (1996). Economic Analysis of Research Spillovers: Implications for the advance technology program. Advance Technology Programme, National Institute of Standards and Technology.

Jeng, L. A. and P. C. Wells (2000). "The determinants of venture capital funding: evidence across countries." Journal of Corporate Finance 6(3): 241-289.

Kortum, S. and J. Lerner (2000). "Assessing the contribution of venture capital to innovation." RAND Journal of Economics 31(4): 674-692. 
KPMG Management Consulting (1999). "An Evaluation of the Small Firms Loan Guarantee Scheme." Department of Trade and Industry, London.

Lahr, H. and A. Mina (2012). "Coaching or Selection? Venture Capital and Firms' Patenting Performance." Centre for Business Research and UK IRC, University of Cambridge.

Lelarge, C., D. Sraer, \& D. Thesmar (2008). "Entrepreneurship and Credit Constraints: Evidence from a French Loan Guarantee Program." in Lerner, J and Schoar, A (eds), International Differences in Entrepreneurship. Chicago: University of Chicago Press.

Lerner, J. (2002). "When bureaucrats meet entrepreneurs: The design of effective 'public venture capital' programmes." The Economic Journal 112: F73-F84.

Lerner, I., I. Pierrakis, L. Collins, \& A. B. Biosca (2011). Atlantic Drift: Venture capital performance in the UK and the US. Research report.

Levitsky, J. (1997). "SME guarantee schemes: a summary." The Financier 4(1\&2): 5-11.

Levitsky, I. and R. N. Prasad (1987). "Credit Guarantee Schemes for Small and Medium Enterprises." Technical Paper No. 58, Industry and Finance Series The World Bank, Washington, DC.

LiPuma, I. A. (2006). "Independent venture capital, corporate venture capital, and the internationalisation intensity of technology-based portfolio firms." International Entrepreneurship Management 2: 245-260.

Llisterri, J. (1997). "Credit guarantee systems: Preliminary Conclusions." The Financier 4(1\&2): 95-99.

Martin, R., P. Sunley, D. Turner (2002). "Taking risks in regions: the geographical anatomy of Europe's emerging venture capital market." Journal of Economic Geography 2(2): 121150.

Mason, C. (2009). "Public Policy Support for the Informal Venture Capital Market in Europe." International Small Business Journal 27(5): 536-566.

Mason, C. and I. Pierrakis (2009). Venture capital, the regions and public policy: the united kingdom since the post-2000 technology crash Hunter Centre for Entrepreneurship. W. P. 09-02.

Mason, C. M. and R. T. Harrison (1999). Public Policy And The Development Of The Informal Venture Capital Market: UK Experience And Lessons For Europe, In: K. Cowling (ed.), Industrial Policy in Europe. London: Routledge.

Maula, M. and G. Murray (2003). Finnish Industry Investment Ltd: An International Evaluation. Ministry of Trade and Industry.

Meyer, R. L. and G. Nagarajan (1996). "Credit guarantee schemes for developing countries: theory, design and evaluation." Africa Bureau of USAID, Barents Group, Washington, DC.

Meyer, T. (2007). The Public Sector's Role in the Promotion of Venture Capital Markets.

Mulcahy, D., B. Weeks, \& H. S. Bradley (2012). We have met the enemy .. and he is us: Lessons from Twenty Years of the Kauffman Foundation's Investments in Venture Capital Funds and The Triumph of Hope over Experience.

Munari, F. (2010). Assessing the impact of public venture capital programs in the United Kingdom: Do regional characteristics matter?

Murray, G. (2007). Venture capital and government policy, In: Landstrom, H. (ed.), Handbook of Research on Venture Capital. Cheltenham: Edward Elgar.

Murray, G. C. (1998). "A Policy Response to Regional Disparities in the Supply of Risk Capital to New Technology-based Firms in the European Union: The European Seed Capital Fund Scheme." Regional Studies 32(5): 405-419.

NAO (2009). Venture capital support to small businesses, The Department for Business, Innovation and Skills.

OECD (2004). Venture capital: Trends and policy recommendations.

OECD (2007). OECD Framework for the Evaluation of SME and Entrepreneurship Policies and Programmes, OECD Publishing.

OECD (2008). Facilitating Access to Finance Discussion Paper on Credit Guarantee Schemes.

OECD (2012). Financing SMEs and Entrepreneurs.OECD Publishing. 
Oh, I., I. D. Lee, A. Heshmati, \& G. G. Choi (2009). "Evaluation of Credit Guarantee Policy using Propensity Score Matching." Small Business Economics 33(3): 335-351.

Pierrakis, I. (2012). Investments and innovation: regional venture capital activity, business innovation and an ecology of interactions. PhD, University of Cardiff.

Popov, A. A. and P. Roosenboom (2012). "Venture Capital and Patented Innovation: Evidence from Europe." Economic Policy 27(71): 447-482.

Reid A. and P. Nightingale, Eds. (2011). The Role of Different Funding Models in Stimulating the Creation of Innovative New Companies. What is the most appropriate model for Europe? A report to the European Research Area Board. Study funded by the European Commission, Directorate-General Research.

Report to the European Commission by an Independent Expert Group (2003). Raising EU R\&D Intensity Improving the Effectiveness of Public Support Mechanisms for Private Sector Research and Development: Guarantee Mechanisms - ISBN 92-894-5576-4.

Riding, A., J. Madill, \& Haines Jr., G. (2007). "Incrementality of SME Loan Guarantees." Small Business Economics 29(1-2): 47-61.

Rigby, J., Bleda, M., Nugroho, Y., \& Morrison, K. (2012). The Role and Importance of Gazelles and Other Growth Firms for Innovation and Competitiveness. Innovation Policy Challenges for the 21st Century, . D. Cox, and Rigby, J. Abingdon, Routledge: 110-134.

Roper, S. (2011). "Credit Guarantee Schemes: a tool to promote SME growth and innovation in the MENA Region." MENA-OECD Investment Programme Working Paper.

Ryan, N. (1990). "Policy evaluation and Australian support for innovation." Technovation 10(4): 265-272.

Saadani, Y., Z. Arvai, \& R. de R. Rocha (2010). "Review Of Credit Guarantee Schemes In The Middle East And North Africa Region." World Bank.

Schaede, U. (2005). Venture Capital as Industrial Policy. Association of Asian Studies. Annual Meeting in Chicago.

Snieska, V. and V. Venckuviene (2011). "Hybrid Venture Capital Funds in Lithuania: Motives, Factors and Present State of Development." Inzinerine Ekonomika-Engineering Economics 22(2): 157-164.

Stiglitz, J. and A. Weiss (1981). "Credit rationing in markets with imperfect information." American Economic Review 71: 457-480.

Storey, D. (1999). Six steps to heaven: Evaluating the impact of public policies to support small businesses in developed economies, In: Sexton, D. L. and Landstrom, H. (eds.), The Blackwell Handbook of Entrepreneurship. Blackwell Publishing.

Sunley, P., B. Klagge, C. Berndt, \& R. Martin (2005). "Venture capital programmes in the UK and Germany: In what sense regional policies?" Regional Studies 39(2): 255-273.

Tether, B. S. and I. Stigliani (2012). Towards a Theory of Industry Emergence: Entrepreneurial Actions to Imagine (not Discover), Create and Nurture (not Evaluate), and Legitimate (not Exploit) a New Market. DRUID 2012. Copenhagen.

Uesugi, I., K. Sakai, \& G. M. Yamashiro (2010). "Effectiveness of Credit Guarantees in the Japanese Loan Market." Journal of the Japanese and International Economies 24(4): 457$\underline{480 .}$

Vogel, R. C. and D. W. Adams (1997). "Costs and benefits of loan guarantee programs." The Financier 4(1\&2): 22-29.

World Bank (2008). "Finance for All? Policies and Pitfalls in Expanding Finance." Washington: World Bank (IBRD).

WTO (2010). European Communities and Certain Member States - Measures Affecting Trade in Large Civil Aircraft. Report of the Panel, WT/DS316/AB/R.

Yong-Protzel, I., U. Brunnhuber, A. Berger, \& Archant (2007). EIF venture capital evaluations: ETF and RCM mandates.

Zecchini, S. and M. Ventura (2009). "The impact of public guarantees on credit to SMEs." Small

Business Economics 32(2): 191-206. 


\section{Annex - Schemes Reviewed}

\section{National Guarantee Fund (NGF), Colombia (Arraiz et al. 2011)}

NGF was created in 1981, but it was not until after 2000 that the number of beneficiaries and the amount of the guarantees became significant. Beneficiaries increased from 8,394 in 1999 to 113,375 in 2008 , and the amount of credit facilitated by the NGF grew from US $\$ 591$ million in 2003 to US $\$ 2578$ million in 2008 , at an annual average rate of $34 \%$ over this five-year period.

NGF was created in 1981, but it was not until after 2000 that the number of beneficiaries and the amount of the guarantees became significant. Beneficiaries increased from 8,394 in 1999 to 113,375 in 2008 , and the amount of credit facilitated by the NGF grew from US $\$ 591$ million in 2003 to US $\$ 2578$ million in 2008 , at an annual average rate of $34 \%$ over this five-year period.

Guarantees offered by the fund are used for working capital, investment, research and development and business creation. Apart from agriculture which has its own scheme, all sectors of the economy are eligible. Loans are guaranteed individually and more than $95 \%$ of the guarantees is approved automatically and does not require any appraisal from the part of the fund. Coverage of the guarantees averaged $48 \%$ in 2008 and this generates incentives for the banks to conduct accurate credit appraisals. Loans default rates were around $4.2 \%$ in 2008 .

The fund also guarantees the portfolio of microfinance institutions.

\section{Partial Credit Guarantee Fund (FORGAPE), Chile (Cowan et al. 2008)}

The Partial Credit Guarantee Fund (FORGAPE) in Chile is administrated by a governmental agency. It has a capital of US $\$ 60$ million, which can be levered up to 10 times. Between 2003 and 2006 approximately 100,000 loans were insured. The average loan was US \$15,000 and $68 \%$ of the principal was insured for an average of 22 months. The maximum term established by law, is 120 months.

The Fund is distributed among financial institutions through a sealed bid auction and institutions freely allocate the insurance among their clients, subject to satisfying the following restrictions:

- Insurance cannot be allocated to loans that have already been issued.

- Only loans below US $\$ 200,000$ can be insured

- The maximum coverage ratio for loans below US\$120,000 is $80 \%$ and above that limit is $50 \%$

- At time loan is issues applicants cannot have payments in arrears in the financial system

- Applicants with sales above US $\$ 1,000,000$ do not qualify for insured loans

A fee is charged for the guarantee but it depends on the past default rate of insured at each institution. Therefore the fee can vary but cannot exceed $2 \%$.

There are three types of insurance offered by the fund: insurance for working capital,

insurance for short term investment, and insurance for long run investment. The insurance for short term investment can be allocated to loans with a maximum maturity of 36 months while 
long term investment can be allocated to loans with a minimum maturity of 37 month and a maximum maturity of 120 months.

Currently there are 17 institutions that use credit insurance, however the 5 biggest financial institutions account for $90 \%$ of the insured loans.

\section{Special Credit Guarantee Program, Japan (Uesugi et al. 2010)}

The credit guarantee system in Japan began in 1937 when the first credit guarantee corporation was established in Tokyo. After the Second World War, the Japanese government established the Small and Medium Enterprise Agency (SMEA), which together with local governments and financial institutions, took initiatives to establish a number of prefectural guarantee corporations. In 1951, the government began to partially insure loan guarantees provided by the prefectural guarantee corporations and the scheme has remained unchanged since. The Japan Finance Corporation for Small and Medium Enterprise is the current insurer and finances $70-80 \%$ of the repayments by the credit guarantee corporations.

During the recessions of the 1970s and 1980s, the government used the guarantee system as a tool to stimulate activity in the SME sector. The Special Credit Guarantee Program (SGS) for Financial Stability was introduced in 1998 and ran to 2001 with purpose of alleviating the severe credit conditions faced by the small business sector. Compared to other credit guarantee program beneficiaries of SGS were not subject to collateral or third-party guarantor requirements. The scale of the SCG program, in terms of funding, was unprecedented. Funding was initially capped at 20 trillion yen, but, in 1999, the cap was increased to 30 trillion yen, which was more than 10 percent of all SME loans outstanding in Japan.

Another unique feature of the SCG program was its lenient examination policy. Applicants could be rejected for a guaranteed loan only under certain conditions: significantly negative net worth, tax delinquency, default, or window dressing of balance sheets. A total of 1.7 million applications worth 28.9 trillion yen were approved.

Credit Guarantee Fund and the Korea Technology Credit Guarantee Fund, Korea (Oh et al. 2009]

There are two major public credit guarantee institutions in Korea that are directed largely at SMEs: the Korea Credit Guarantee Fund (KCGF) and the Korea Technology Credit Guarantee Fund (KOTEC). The former, established in 1976, provides credit guarantee services for the liabilities of promising firms that lacked the credit rating to attract investment while the latter, established in 1989, focuses on providing support to new technology-based enterprises.

The objective of KCGF is to lead the balanced development of the national economy by extending credit guarantee services for the liabilities of promising enterprises which lack tangible collateral and by stimulating sound credit transactions through the efficient management and use of credit information. KOTEC was founded in 1989 under the Financial Assistance to New Technology Businesses Act, which went through a full-scale revision and was newly titled Korea Technology Credit Guarantee Fund Act in 2002. The mission of KOTEC was to contribute to the national economy by providing credit guarantees to facilitate financing for new technology-based enterprises while promoting the growth of technologically advanced SMEs and venture businesses. 
The amount of credit guaranteed by government soared and it reached almost 6-8\% of GDP, which is higher than other countries, except for the Japanese case which maintained guarantee balance to GDP ratio as high as Korea, e.g. $0.1 \%$ in USA, and $0.02 \%$ in UK, $0.2 \%$ in Germany in 2004.

\section{Canadian Small Business Financing Programme (CSBF), Canada (Riding et al. 2007)}

Established in 1961, the Small Business Loans Act the programme was renamed the CSBF in 1999. It provides financing for term loans for capital investments but not working capital. Similar to the UK Small Firm Loan Guarantee Scheme the Canadian scheme relies on portfolio management with loan and guarantee approval being undertaken by the lender. Borrowers pay a 2 per cent registration fee and a small annual fee with both being passed on to the guarantor.

Small businesses or start-ups operating for profit in Canada, with gross annual revenues of $\$ 5$ million or less are eligible for support. Loans of up to a maximum of $\$ 500,000$ are available for any one borrower, of which no more than $\$ 350,000$ can be used for purchasing leasehold improvements or improving leased property and purchasing or improving new or used equipment.

\section{UK - Small Firms Loan Guarantee, UK (Cowling 2010)}

The Small Firms Loan Guarantee (SFLG) was first established in 1981 and was the Government's principal debt finance instrument that supports access to finance for small businesses. Throughout the scheme's history tens of thousands of businesses have been supported through SFLG, with around 4,500 businesses supported per year in the last decade. The guarantee covers up to $75 \%$ of qualifying loans of amounts up to $£ 250,000$. In return for the guarantee, the borrowing business pays BIS an annual premium of two per cent of the outstanding balance of the loan, assessed and paid quarterly. Businesses can not apply for SFLG directly, as SFLG operates as a tool for the lender to use at their discretion alongside their normal commercial lending practices.

SFLG is therefore seen as operating at the margins of commercial lending and is not designed to replace mainstream lending decisions. However, SFLG is often used as part of an overall package of finance that borrowers put together. It is estimated that SFLG accounts for roughly $1 \%$ of all SME lending by value.

\section{Sofaris - Creation Fund, France (Lelarge et al. 2008)}

The 'SOFARIS' program was set up in the late 1980s and was initially restricted to firms active in the manufacturing and business services industries. It is a semi-public agency with the French state owning $50 \%$ of voting rights and a consortium of private banks and public financial institutions owning the remaining $50 \%$.

SOFARIS is divided into four main funds, each having specific objectives but it is the 'Creation Fund' improves credit access for new ventures, mostly through medium-to-long term loans. In 1995, the public endowment of the program was increased and new industries (construction, retail and wholesale trade, transportation, hotels and restaurants and personal services) became eligible. Sofaris is the French equivalent of the SBA 7(a) Loan program but unlike in the U.S. firms do not have to prove that they were unable to obtain credit on the regular market. 
Applications for SOFARIS guarantees are made by banks. Once granted, a guarantee allows the bank to recover between $40 \%$ and $70 \%$, of the remaining loan principal in case the firm defaults. This fraction is determined at the fund-year level, with the view to manage the aggregate risk faced by the SOFARIS agency. Benefiting firms pay a fee, also set at the fund-year level, which adds to the interest rate it has to pay to the bank. This fee usually varies between $0.5 \%$ and $1.5 \%$ of the loan value.

In 2005, the Creation Fund was used to guarantee one third of a total of 4.5 billion euros total expenditure of SOFARIS. Some 26,000 firms (of the total 40,000 firms backed by a SOFARIS guarantee) benefited from such early stage loan guarantees.

Fund for Guarantee to SMEs (SGS), Italy (Zecchini and Ventura 2009)

Italy's credit guarantee system, it based on a mix of private and public funding with mutual guarantee institutions acting at the grass root level, private banks acting as intermediaries providing the actual guarantee to business enterprises and public funds, set up at State and Regional government levels, for the purpose of offering guarantees, insurance and/or reinsurance services to the institutions involved. The SGS is the biggest one of three state funds actually operating at the third level in the system. It was established in 1996 and offers direct guarantees to lending banks, co-guarantees with other guarantor institutions, and provides guarantees of last resort to MGIs

In 2005 the Fund's guarantee capacity was 233.5 million euros but a gearing ratio allowed it to guarantee loans amounting to 4.6 billion euros, equivalent to around $3 \%$ of total lending for SMEs in sectors covered by the fund. 


\section{Manchester Institute of Innovation Research}

The Manchester Institute of Innovation Research (MloIR) is the research centre of excellence in the Manchester Business School (MBS) and The University of Manchester in the field of innovation and science studies. With more than 50 full members and a range of associated academics from across the University, MloIR is Europe's largest and one of the World's leading research centres in this field.

The Institute's key strengths lie in the linkage and cross-fertilisation of economics, management and policy around innovation and science. Building on forty years of tradition in innovation and science studies, the Institute's philosophy is to combine academic rigour with concrete practical relevance for policy and management. This includes broad engagement with and research for policy makers and societal and industrial stakeholders in the Manchester City Region, across the UK and internationally. MloIR is also firmly committed to a range of teaching activities within and beyond MBS and integrates a strong and successful PhD programme into its research activities. The Institute has a visitor programme for academics and management and policy practitioners and provides a range of popular and high level executive education courses on evaluation, foresight and S\&T Policy. 